\title{
WAS THERE REALLY AN EARLIER PERIOD OF INTERNATIONAL FINANCIAL INTEGRATION COMPARABLE TO TODAY?
}

\author{
Michael D. Bordo \\ Barry Eichengreen \\ Jongwoo Kim \\ Working Paper 6738 \\ http://www.nber.org/papers/w6738 \\ NATIONAL BUREAU OF ECONOMIC RESEARCH \\ 1050 Massachusetts Avenue \\ Cambridge, MA 02138 \\ September 1998
}

Paper prepared for the Bank of Korea Conference, "The Implications of Globalization of World Financial Markets," Westin Chosun Hotel, Seoul, Korea, June 22 -23, 1998. For helpful comments and suggestions we thank Sir Allan Budd, Lex Hogduin, Allan Meltzer, Anna Schwartz, and Mira Wilkins. The views expressed here are those of the authors and do not reflect those of the National Bureau of Economic Research.

(C) 1998 by Michael D. Bordo, Barry Eichengreen, and Jongwoo Kim. All rights reserved. Short sections of text, not to exceed two paragraphs, may be quoted without explicit permission provided that full credit, including $(\mathcal{C}$ notice, is given to the source. 
Was There Really an Earlier Period of International

Financial Integration Comparable to Today?

Michael D. Bordo, Barry Eichengreen,

and Jongwoo Kim

NBER Working Paper No. 6738

September 1998

JEL No. F21, F32, E42, N20

\section{ABSTRACT}

In this paper we reconsider the " $U$ " shaped pattern in international market integration, starting at high levels in the late nineteenth century, collapsing between the wars, and recovering gradually after 1945 to reach levels comparable to pre-1914 in the 1990 's. The empirical evidence we survey suggests that in some respects the financial integration of the pre-1914 era remains unsurpassed, but in others today's financial markets are even more closely integrated than those in the past. The difference today is that new information-generating and processing technologies have reduced the market-segmenting effects of asymmetric information. In consequence, the range of financial claims that are traded internationally has broadened. While international financial transactions were once determined by claims on governments, railroads, and mining companies, entities with tangible and therefore relatively transparent assets, international investors now transact freely in a much broader range of securities.

Michael D. Bordo

Department of Economics

Rutgers University

New Brunswick, NJ 08903

and NBER

bordo@fas-econ.rutgers.edu
Barry Eichengreen Department of Economics University of California Berkeley 549 Evans Berkeley, CA 94720 and NBER eichengr@econ.berkeley.edu

\section{Jongwoo Kim}

Department of Economics

Rutgers University

New Brunswick, NJ 08903

jwk@rci.rutgers.edu 


\section{Was There Really an Earlier Period of International Financial Integration Comparable to Today? Michael Bordo, Barry Eichengreen and Jong Woo Kim}

\section{Introduction}

It is now fashionable to assert that the 1990 s are the second modern era of global finance, the first having been prior to World War I. In the years leading up to the Great War, it is said, international financial markets were even more integrated than today. National markets were bound together by the corset of the gold standard. Capital flowed across borders undeterred by currency risk or exchange controls. Interest rates on government bonds denominated in different currencies converged strongly (McKinnon, 1988). International capital movements, scaled by the incomes of the countries concerned, reached levels never matched subsequently (Bayoumi, 1990). The integration of capital markets was reinforced by and in turn reinforced the integration of labor and commodity markets. International migration reached high levels (Hatton and Williamson, 1998), and the growth of trade outstripped the growth of incomes (O'Rourke and Williamson, 1998).

World War I relegated this rosy state of affairs to history's dustbin. Capital controls, tariffs, and restrictions on migration proliferated, a trend which accelerated in the crisis-ridden 1930s and 1940s. After World War II, however, the tide turned. The Bretton Woods Agreement promoted the resumption of current account convertibility, while the GATT encouraged the reduction of tariffs and the multilateralization of trade. For a time, capital controls remained. But with the recovery of confidence in the benefits of economic and financial openness and advances in information and communications technologies that have made it harder to close off national markets from international 
transactions, capital mobility has trended ineluctably upward. The world today, it is said, is reverting to a pre-1914 future. ${ }^{1}$ And if financial integration and economic integration more generally trace out a u-shaped pattern, starting at high levels in the late-19th century, collapsing between the wars, and recovering gradually after 1945 , then there is nothing new or unprecedented about the current financial environment in which domestic economies are tightly integrated into the world capital market, and economic policies are constrained.

In this paper, we reconsider this "back-to-the-future" scenario, concluding that the analogy with the 19th century should not be pushed too far. In some respects the financial integration of the pre-1914 era remains unsurpassed, but in others today's financial markets are more even closely integrated than those of the past. The difference today is that new information-generating and processing technologies have reduced the marketsegmenting effects of asymmetric information. In consequence, the range of financial claims that are traded internationally has broadened. Where international financial transactions were once dominated by claims on governments, railroads and mining companies, entities with tangible and therefore relatively transparent assets, international investors now transact freely in a much broader range of securities. In addition, direct foreign investment is no longer dominated by investments in free-standing resourceextracting companies often operating under the wing of protective colonial governments; instead, the vehicle today for DFI is multinational firms, which are present in virtually every country and all manufacturing and service activities.

\footnotetext{
1 A representative statement of the thesis is Zevin (1992), who argues that "while financial markets have certainly tended toward greater openness since the end of the Second World War, they have reached a degree of integration that is neither dramatic nor unprecedented in the larger historical context of several centuries" (p. 43).
} 
Section 2 documents the u-shaped pattern of financial integration that spans the last 100 years. Section 3 seeks to understand these changes in the extent of international financial integration over time. Section 4 highlights the changes in the operation of international financial markets induced by technological and financial innovation. Section 5 , in concluding, returns to the lessons of history.

\section{The Dimensions of Capital Market Integration}

In this section we review and extend the empirical literature on financial market integration from 1880 to today.

\subsection{Net Capital Flows}

The 50 years before World War I saw massive flows of capital from the core countries of western Europe to the overseas regions of recent settlement (mainly the rapidly-developing Americas and Australasia). ${ }^{2}$ At its peak, the outflow from Britain reached 9 percent of GNP and was almost as high in France, Germany, and the Netherlands (Bairoch and Kozul-Wright 1996). ${ }^{3}$ Private capital moved essentially without restriction. Much of it flowed into bonds financing railroads and other infrastructure investments and into long-term government debt. ${ }^{4}$ Figure 1 shows five-year moving averages of the mean absolute value of the ratio of the current account balance to GDP for 12 countries. ${ }^{5}$ Figure 2 shows current account balances for one large capital exporter, the

\footnotetext{
${ }^{2}$ Extensive international financial market integration began well before 1880. Neal (1990) documents the integration that occured in northwest Europe after 1700. Capital flows from Britain to the United States, Latin America and the British colonies accelerated in the years after the Napoleonic wars (Zevin 1992).

${ }^{3}$ This compares with the peaks in Japan's and Germany's current account surpluses in the mid- and late 1980s of 4-5 percent of GDP.

${ }^{4}$ Although there was also significant direct foreign investment, as we explain below.

5 The countries in this sample which we label Group 1 are Argentina, Australia, Canada, Denmark, Finland, France, Germany, Italy, Japan, Norway, Sweden, United Kingdom, United States. However, we did not include
} 
United Kingdom, one large capital importer, Canada, and the largest "emerging market," the United States. ${ }^{6}$ A striking feature of this data is the size and persistence of current account deficits in the pre-1914 period, especially in Australia, Canada, Argentina, and the Nordic countries and of the current account surpluses of the UK and France. ${ }^{7}$

For comparison, Figure 3 shows the mean absolute value of the ratio of current account to GDP for 23 of today's emerging markets (countries whose GDP exceeded 30 billion dollars and were classified as indebted countries by the World Bank) using data from the International Monetary Fund's International Financial Statistics for the period 1949 to $1996 .^{8}$ These countries have been running current account imbalances under the recent managed float averaging 4.1 per cent of their GDPs, which is similar to the average for the prewar sample of 3.9 per cent which includes both capital importers and exporters. $^{9}$

Capital flows for the 13 prewar countries are also considerably less variable (the standard deviation in $1880-1913$ was 2.7 per cent versus 4.1 per cent under the managed floating regime). In the interwar period Group 1 countries' current account ratios were

Finland in Figure 1. All of these countries except Argentina graduated from emerging country status to advanced country status. For explanations for Argentina's retardance see e.g. Taylor (1997). We kept Argentina in the sample past World War II even though it clearly belongs with the Group 2 countries discussed below because of its major importance as a capital recipient before 1914 .

${ }^{6}$ Recently the standard series on current account balances have been revised by Jones and Obstfeld (1998) to account for nonmonetary gold flows under the pre-1914 and the interwar gold standards. The problem with the standard sources, as Jones and Obstfeld explain, is that their designers did not distinguish monetary gold exports, which are capital account credits, from non-monetary gold exports, which are properly included in the current account. Jones and Obstfeld adjust for these discrepancies, and this is the data we present in Figures 1 and 2. See Appendix Figure 1 for the individual country data.

${ }^{7}$ The United States exhibited current account deficits comparable to these countries earlier in the nineteenth century.

${ }^{8}$ The individual country data for this sample which we label Group 2 are in Appendix Figure 1. The countries are: Algeria, Brazil, Chile, China, Colombia, Egypt, Hungary, India, Israel, Korea, Malaysia, Mexico, Morocco, Pakistan, Peru, Phillipines, Poland, Romania, South Africa, Thailand, Turkey, and Venezuala.

${ }^{9}$ For a sample of just capital importers, the ratio was 4.4 per cent. (See Tables 1 and 2 which show the mean and the standard deviation of the data for each country across 4 exchange rate regimes from 1880 to the present.) 
about as variable (standard deviation of 3.8 per cent) as for the Group 2 countries under the float (standard deviation of 4.1 per cent) (See Tables 1 and 2.)

\subsection{The Persistence of Current Account Deficits}

Tables 3 and 4 present evidence on the persistence of current account balances for the two samples of countries. We present the coefficients of an AR(1) regression and standard errors as well as the augmented Dickey Fuller (ADF) test for persistence. The lag lengths, determined by the Aikake Information Criterion (AIC), vary from zero to two. For the comparison among regimes, we only include a constant and one lag and do not include a trend.

From Table 3 we learn that the average current account for the 13 countries exhibited significant persistence in all periods except that between the wars, with the recent float showing the most persistence. If however we focus just on the major capital importers of the pre-1914 era (Canada and Australia), we see more persistence under the gold standard than today. The same is true of the major capital exporters, the UK and France. The Phillips-Perron $Z_{t}$ test statistic is higher for the longer sample of 23 emerging countries in recent decades than for the 13 countries prior to 1914 , indicating less persistence (see Table 4).

Additional evidence can be gleaned from the variance ratio. ${ }^{10}$ Defined as the ratio of $1 / \mathrm{k}$ times the variance of the series $\mathrm{k}$ differences divided by the variance of first differences, the variance ratio is the variance of the unit root component of a series relative to the variance of the trend stationary component. If the ratio exceeds one, the series contains a substantial unit root and is difference stationary. It has strong

${ }^{10}$ See Cochrane (1988) and Bordo and Schwartz (1997). 
persistence. When it is less than one, the unit root represents a much smaller fraction of the variance of the series and exhibits moderate persistence. When it is zero, the series is trend stationary and does not exhibit persistence.

Figure 4 shows the variance ratio for the current account to GDP ratio for the mean of the countries in Group 1. Figure 5 shows the same ratio for the 23 countries in Group 2. As can be seen from Figure 4, persistence was the greatest for the gold standard period, followed by the interwar. It was least under Bretton Woods.

Figure 5 for today's emerging markets shows little difference between the two postwar regimes. In neither case can the null hypothesis of a unit root be rejected at the $5 \%$ significance value. In both recent periods the ratio declines towards zero more rapidly than was the case under the classical gold standard. It also suggests that the degree of persistence is less for the countries in Group 2 than for those in Group 1.

\subsection{Savings-Investment Correlations}

A widely-used measure of financial integration is the correlation between national savings and investment rates. In a 1980 article, Feldstein and Horioka argued that if international capital markets are well integrated, this correlation should be low because investment can be financed by foreign capital flows. Their regression results for the $1960 \mathrm{~s}$ and 1970 s found a high coefficient from regressing the investment rate on the savings rate for a cross section of OECD countries. ${ }^{11}$ They interpreted this as evidence of low capital mobility in a period when conventional wisdom posited the opposite. An enormous literature followed, some of it historical. ${ }^{12}$ Bayoumi (1990) extended the Feldstein-

\footnotetext{
11 Using data averaged for five-year periods.

${ }^{12}$ A recent review of the literature is Coakley, Kulasi and Smith (1998).
} 
Horioka approach to the classical gold standard, finding a much lower correlation and inferring from this that capital markets were better integrated prior to 1913. Similar results are provided by Zevin (1992). Eichengreen (1992) uses a larger sample of countries and concludes in favor of lower overall capital mobility than Bayoumi, although even in his extended data set the correlation of national savings and investment rates is significantly below that reported by Feldstein and Horioka. ${ }^{13}$

Recent research by Taylor (1996) goes some way toward reconciling these findings for different periods and samples. Using data for 12 countries from 1850 to 1992, Taylor's estimated coefficients trace out an inverted u shape over time. On this basis he concludes that capital markets were well integrated before 1914 , that they then ceased being so except in the short period of time during which the interwar goldexchange standard prevailed, and that they have become gradually more integrated since 1950 s, with coefficients in the 1990 s again reaching the levels of the pre-1914 period (See Figure 6). ${ }^{14}$

\subsection{Covered Interest Parity}

Another indicator of capital mobility is a comparison between interest rates on assets in different financial centers. ${ }^{15}$ Marston $(1993,1995)$ presents evidence based on this approach for key advanced countries following the demise of the Bretton Woods System. Obstfeld and Taylor (1998) apply his methods to the longer period 1870-1990 for the U.S. and UK. As reproduced in Figure 7, their results based on 60 day bank bills and

\footnotetext{
${ }^{13}$ These conclusions have recently been affirmed by Jones and Obstfeld using their revised data.

${ }^{14}$ Taylor (1994) presents supporting evidence explaining some of the anomalous coefficients by omitted demographic variables. Taylor (1996) also uses an error correction methodology to distinguish between shortrun shocks and the long-run equilibrium.

${ }^{15}$ Among other things, this comparison rules out pure country risk.
} 
other instruments indicate a negligible differential in the years before 1914. A similar pattern is observed under Bretton Woods in the 1960s and again in the most recent decade. ${ }^{16}$

Thus, these results are consistent with the null of relatively high levels of financial integration both prior to 1914 and recently.

\subsection{Real Interest Parity}

A more stringent test is real interest parity, which requires both uncovered interest parity and purchasing power parity (Obstfeld 1995). A recent study by Lothian (1995) of divergences in ex post short-term and long-term real interest rates for a panel of 10 countries from 1880-1995 finds low divergence under the classical gold standard, Bretton Woods and the recent float alike, but the lowest divergence is in the most recent 10 years of the float.

Deviations from real interest parity are shown in Figure 8a, which plots the dispersion (standard deviation) of annual ex post real long-term bond yields for our sample of 12 countries from 1870 to $1994 .{ }^{17}$ Figure $8 \mathrm{~b}$ presents a similar calculation using monthly data on the ex ante real interest rate for short-term securities ( 3 month bank bills) for the four core countries of the gold standard (UK, US, France, Germany). ${ }^{18}$ A similar pattern is observed for long-term securities. Both figures show clear evidence of capital market integration before World War I and in the most recent decade,

\footnotetext{
${ }^{16}$ For supporting evidence on uncovered interest parity for the U.S. and U.K. in the gold standard period 18791914, see Calomiris and Hubbard (1996). These studies test for arbitrage in short-term financial securities. Bordo and Rockoff (1996) focus on the yields on long-term securities for 9 capital importing countries in the period 1890-1914. They show marked convergence in the nominal yields of both gold and paper securities after 1900 to the yield on British consols. Before 1900 gold yields moved closely with the consol yield.

${ }^{17}$ We omitted Argentina from the calculation because its experience of high and variable inflation since World War II made its real interest rate considerably more volatile than that typical of countries in Group 1.

${ }^{18}$ For an explanation of how this series was calculated, see below.
} 
bracketing a period of massive disintegration.

\subsection{Evidence from Cointegration}

One can also test whether a cointegrating vector (which is a measure of a long-run equilibrium relationship) exists between the real short-term interest rates of the four core countries of the international monetary system (U.S., U.K., Germany, France). We do so across 4 regimes: the classical gold standard (1880-1914); the interwar period (19191939); Bretton Woods (1957 to 1970); and the present managed float (1971 to 1998), where we divide the last of these into high inflation (1971 to 1982) and low inflation (1983 to 1998) sub-periods.

To calculate ex ante short-term real interest rates we subtract a measure of expected inflation from the nominal short-term (seasonally adjusted three-month bill) rates for the 4 core countries. ${ }^{19}$ Figure 9 displays an eleven-month moving average of these nominal interest rate series. Tables 5 and 6 report the basic statistics and persistence tests for the nominal rates. As expected, regimes with fixed exchange rates (the gold standard and Bretton Woods) had the smallest deviations calculated by the mean of the standard deviation among the four nominal interest rates.

The augmented Dickey-Fuller test is used to test for persistence. The lag lengths, which are decided by the Akaike Information Criteria (AIC), vary from zero to two months by countries and regimes. For the comparison among regimes, we only include a constant and do not include a time trend or lags.

For all level variables, the null hypothesis of a unit root cannot be rejected at the $5 \%$ significance level (based on the Phillips-Perron $Z_{t}$ test statistic, critical value $(0.05)=$

\footnotetext{
19 The data sources are Bordo and MacDonald (1997) for the pre-World War I gold standard, Bordo and MacDonald (1998) interwar and IFS for post-World War II.
} 
2.93). However, the null hypothesis is rejected for the first difference of each variable except for the Bretton Woods period.

To calculate the ex ante real interest rate we require a measure of expected inflation. Using the Instrumental Variable method, we first calculate the expected inflation rate by regressing inflation on 12-month lags of the inflation rate (an AR(12) process). The expected inflation rate is then subtracted from the nominal rate. ${ }^{20}$

Tables 7 and 8 report the basic statistics and persistence tests for short-term real interest rates plotted in Figure 10. The mean standard deviation among the 4 countries' real rates is lowest for Bretton Woods and the recent low inflation floating period (19831998). For the classical gold standard it is considerably higher.

Valid inference using the Error Correction Model (ECM) requires that the variables in the system be an $I(1)$ process, which means that the level of a variable is a unit root but the first difference is a stationary process. For all the original level variables, the null of a unit root cannot be rejected at the 5\% significance level using the augmented Dickey-Fuller test. However, the null is rejected conclusively for the first order difference of each variable. Hence, all real interest rates are $I(1)$ processes.

To test for cointegration among the real interest rates for the four countries, we estimated a VECM (Vector Error Correction Model). We write the VECM as:

$$
\Delta X_{t}=c+\Gamma_{1} \Delta X_{t-1}+\ldots+\Gamma_{k-1} \Delta X_{t-k+1}+\Pi X_{t-1}+\epsilon_{t}
$$

\footnotetext{
${ }^{20}$ Our method is robust compared to other methods to calculate real interest rates. Calculations of ex post real interest rates using monthly data reveal the calculated real interest rate to be extremely volatile because actual inflation movements dominate movements in nominal interest rates. Another method is the moving average method used by Lothian (1995). This method does not have any weights for the lagged inflation rates. Thus the previous month's inflation rate and the inflation rate from twelve months ago are treated as the same when economic agents forecast future inflation rates.
} 
where $X_{t}$ is an $n \times I$ vector of $I(1)$ variables and $\Delta X_{t}$ is the vector of changes in period t. $X_{t}$ is the real interest rates for the four countries. The coefficient matrix of the difference VAR, $\Gamma$, represents the short-run dynamics. In addition to the short-run dynamics, the VECM produces a long-run relationship. II represents the long-run matrix and the rank $r$ determines the number of stationary linear combinations of $X_{r}$. For $0<r<n$, there exist $\mathrm{r}$ cointegration vectors. In that case, $\Pi$ can be factorized as $\alpha \beta^{\mathrm{T}}$, where both $\alpha$ and $\beta$ are $n \times r$ matrices. The series are linked together over time by the long-run relations in $\beta^{\mathrm{T}}$, ensuring that the series never move too far apart. $\alpha$ represents the error-correction parameters, which can be interpreted as the speed of adjustment to a shock in the system.

We first conducted the recursive Johansen Likelihood Ratio Test to test for the stability of the cointegrating relationship $\left(\beta^{\mathrm{T}}\right)$ as suggested by Bremnes, Gjarde and Seltem (1997). Since each regime has a different sample size and the test is sensitive to sample size, we fixed the window size at 60 months and updated it by rolling. The null hypothesis is that there is no cointegration vector. If financial markets are integrated, the test statistics should be greater than the critical value, and we should be able to reject the null hypothesis.

Table 9 shows the test statistics, which are plotted in figure 11. The low-inflation floating rate subperiod has the largest test statistic, allowing us to reject the null hypothesis at any level of significance. Next largest is that for the high-inflation floating rate subperiod. The smallest test statistic is that for the Bretton Woods period, where we cannot reject the null at any level of significance. Thus, these results suggest that financial markets in the recent floating exchange rate period are more stably integrated than in any other regime. 
Next, we factorize $\Pi$ as $\alpha$ and $\beta$ to measure the speed of adjustment to long-run equilibrium following shocks. Based on the Johansen Likelihood Ratio Test, we assume that each regime has one cointegrating vector. Table 10 reports the estimated $\alpha$ which shows how rapidly the series adjust to their long-run relationship, where a large coefficient signifies rapid adjustment. The gold standard has the largest coefficient. Next is that for the high inflation floating exchange sub-period. The smallest coefficient is that for the interwar years. ${ }^{21}$ A possible reason why the recent float is more cointegrated than the gold standard yet the gold standard has the fastest response to shocks is the greater role of activist monetary policy in the recent regime, if one believes that domestic stabilization policy and exchange market intervention in the past decade could have slowed the adjustment process.

We interpret these results as providing further evidence for the $\mathrm{u}$-shaped pattern of international financial market integration. But the greater degree of cointegration in the recent data may be evidence of closer financial market integration today than in the past. The slower adjustment to shocks in the most recent period compared to the gold standard, on the other hand, is likely the consequence of policy actions in a more managed regime than existed before 1914. Qualitative evidence, in Section 4 below, provides further support for this view. ${ }^{22}$

\section{Explanations for the High Level of Prewar Capital Flows}

\footnotetext{
21 Impulse response functions based on a VAR model produced a similar ordering to the ECM. However the size of the shocks under the gold standard greatly exceeded those under the present regime making the interpretation less clear-cut.

22 An alternative hypothesis is that "noise trading" under the recent float may have impeded adjustment.. See DeLong (1987).
} 
A number of factors could explain the larger size and greater persistence of current account imbalances in the pre-1913 period. One is the greater credibility of policymakers' commitment to stable monetary and fiscal policies as manifested in adherence to the gold standard. The gold standard provided a signal that the borrowers followed the same rules as lenders in the metropolitan centers and hence were unlikely to default on their debts. Bordo and Rockoff (1996) evaluate this hypothesis for nine recipients of British capital in the period 1870-1914 and find strong evidence that good gold standard adherents paid lower interest rates on sovereign debt than those with spottier records. Flandreau, Le Cacheux and Zeumer (1998) find similar results for a different panel of European peripheral countries, as do Sussman and Yateh (1998) for Japan. Insofar as the gold standard proxied for fiscal rectitude and for adherence to similar norms among the capital recipients as well as the senders, the failure of the international monetary system to support equally persistent deficits after World War I may reflect a shift to less credible policies.

A related and possibly important determinant of the extent and persistence of British capital exports was the fact that most British investment went to former colonies where the British heritage was strong. These countries (e.g., the U.S., Canada and Australia) shared a common language, culture, legal system, and accounting system. British capital also went to countries like Argentina and Uruguay where Britain had long had a strong commercial presence and considerable political influence, or to colonies under direct British control. The French also directed their lending to countries where they had a strong political influence and close cultural ties, e.g. Italy, Spain, and Russia (see Fishlow (1985) and Flandreau (1998)). By comparison, today's capital recipients 
tend to be very different in the above respects from the capital exporters. It follows that the latter may be less willing to maintain foreign investment in the face of adverse shocks.

Another explanation may lie in the nature of the investment itself. Much of the capital flowing to the New World went to finance railroads and other infrastructure. This investment required a long-term commitment because of its very nature: because the returns accrued only when the project was completed, rendering it costly to terminate early. Although there is considerable infrastructure investment in today's emerging countries, it does not dominate to the same extent. ${ }^{23}$

Moreover, insofar as prewar investment, and British investment in particular, was investment in traded-goods-related sectors--as emphasized by Fishlow (1985), it went into export-related infrastructure and natural-resource related projects that in the normal course of events generated a stream of foreign exchange revenues sufficient to pay the money back--it did not give rise to balance-of-payments problem. And the fact that preWorld War I lending took place in an environment of relatively free multilateral trade allowed countries that engaged in significant amounts of external borrowing to expand their exports as needed to amortize those debts.

\footnotetext{
${ }^{23}$ We experimented with some econometric tests for possible determinants of current account persistence across monetary regimes. We regressed the current account ratio for cross-sections of our 2 panels of countries on a number of variables. These included the absolute level of GDP, the difference between the level of per capita income in the lending and the receiving countries (the UK as lender pre 1914, the U.S. since); and dummy variables to capture the exchange rate regime, common language and customs, trade connections and capital controls. For Group 1 we found across all regimes three variables to be significant: the absolute level of income (a proxy for country size); the per capita income gap ( however the sign was perverse in a number of cases); a dummy for Europe. Also the exchange rate dummy was significant under gold standard consistent with the Bordo-Rockoff study. For Group 2, only the level of GDP, a dummy for Asia and the dummy for capital controls were significant. However the last variable has a perverse sign in Bretton Woods. We then tested for structural breaks in the regressions using a rolling Chow test procedure. Significant breaks were found to occur during financial crises: in the 1890s and 1907 under the gold standard; in the 1930s; in 1970-73 under Bretton Woods and in the early 1980 s under the managed float.
} 
A final explanation may lie in the flexibility of 19 th century economies. Insofar as their markets were less structured and institutionalized and adjustment was less constrained by policy and powerful interest groups, a shift in capital flows which implied the need to reallocate resources between sectors producing traded and nontraded goods could be accommodated easily. Bayoumi and Eichengreen (1996) and Calomiris and Hubbard (1996) provide econometric evidence consistent with this interpretation.

\subsection{Contrasts Between Periods}

While integration measured in terms of net capital flows as a percentage of GDP is quite similar in post-1975 and pre-1914 periods, gross flows are greater today. Bank for International Settlements data on turnover in the foreign exchange market suggest that gross flows are in the range of $\$ 1.25$ trillion a day, or more than $\$ 250$ trillion a year. $^{24}$ While there exist no comparable estimates of gross short-term capital flows in the pre1913 era, Bloomfield's (1963) discussion suggests that these were much lower relative to long-term flows than they are today.

A second important difference is the sectoral/functional composition of the investment. Although data on the composition of pre-1914 portfolio investment are incomplete, probably the best (though still limited) estimates are those for Great Britain, the leading creditor of the period. (British investors held about 40 per cent of the stock of long-term foreign investments outstanding in 1913 according to conventional estimates. In terms of composition, there is no reason to think that Britain is grossly unrepresentative.) These suggest that, circa 1913, fully 30 per cent of British overseas

\footnotetext{
24 See BIS (1997).
} 
investments in quoted securities was in the issues of governments and municipalities, 40 per cent in railways, 10 per cent in resource-extracting industries (mainly mining), and 5 per cent in public utilities. ${ }^{25}$ Thus, fully 85 per cent of overseas portfolio investment was in the securities of entities with highly tangible and transparent assets, be these the ability to tax or the possession of resource reserves, railway track, or telegraph and telephone lines. To be sure, investment in government bonds and infrastructure projects is still disproportionately important today, but the absence from this list of commercial, industrial and financial concerns is nontheless striking. Portfolio investment in such companies, whose assets are necessarily less tangible and whose operations were by implication less transparent, appears to have been considerably less important in the prewar era of globalization than in the present day.

Third, the relative importance of debt and equity has changed, reflecting the recent expansion of "emerging" stock markets. The most recent issue of the World Bank's Global Development Finance estimates that stocks and bonds are now of roughly equal importance. Prior to 1913, the vast majority of portfolio capital flows took the form of bonds, not equity.

Fourth, the balance between portfolio and direct foreign investment has changed. Whereas today direct investment is as important as portfolio investment, this was not the case before 1914. Bloomfield (1968, pp.3-4) puts it strongly. "Portolio investment was a far more important component of long term capital movements before 1914 than direct investment..." China was the one prominent exception to this rule. In contrast, since World War II direct investment has consistently exceeded portfolio investment. While

\footnotetext{
25 These estimates, from Royal Institute for International Affairs (1937), are based on the earlier work of Herbert Feis.
} 
securities markets have grown explosively in recent years, around half of all capital flowing to emerging markets is still in the form of direct investment. ${ }^{26}$

Fifth and finally, the nature of that direct foreign investment has changed. Before 1914 , according to Wilkins (1998), DFI was undertaken mainly by free standing companies--companies incorporated in the U.K., France, Belgium, and a few other Western European countries for the purpose of investing and doing business in an emerging market. ${ }^{27}$ These enterprises proliferated in mining, agriculture and transportation, as in the cases of, inter alia, Rio Tinto and the Suez Canal Company. Today, in contrast, DFI is done through multinational enterprises, whose operations involve the extension across borders not just of financial capital but of the firm's preexisting managerial and productive capabilities. ${ }^{28}$

\subsection{Understanding the Differences}

These differences across time are best understood as consequences of the

\footnotetext{
${ }^{26}$ Subsequent research has modified this picture, upgrading the importance of DFI, without overturning it.

27 According to Wilkins, 'classic' multinational enterprises in which firms maintained operations in many countries became an increasingly important conduit for foreign direct investment over the period being discussed here.

${ }^{28}$ We were unable to put together a complete record of the global composition of foreign investment between portfolio and foreign direct investment for the world for our century of experience. Twomey (1998) and Kregel (1994), however, have assembled some of the data. Twomey presents a breakdown into portfolio and direct investment for the world from 1900 to 1938 which shows a significant increase in the share of foreign direct investment (FDI) in the total from 1914 to 1938 from $31 \%$ to $48 \%$. For developing countries FDI represented two-thirds of foreign investment until World War II. Since then FDI to LDCS has declined significantly relative to the industrialized nations. According to Kregel, FDI increased relative to portfolio investment during the post-WWII Bretton Woods period but since the 1980s there has been a resurgence of portfolio investment.

We were also unable to compile the data to give us a clear picture of the long-run pattern of the breakdown between short-term and long-term capital flows. According to Bloomfield (1963) and Wilkins (1998) based on very limited data of commercial bank foreign obligations as well as official reserve movements, short-term capital flows, while crucial to the adjustment mechanism of the classical gold standard, were small relative to the long-term capital movements. In the interwar, limited data in United Nations (1949) and Nurkse's (1944) narrative suggests that short-term capital movements during the turbulent years of the 1930s swamped long-term movements. In the postwar Bretton Woods period in the presence of capital controls, private shortterm capital flows were limited. Of greater importance were changes in official reserves to accommodate balance of payments disequilibrium. Since 1971 short-term capital movements, especially bank loans, have increased in size and importance (Kregel, 1994) However, because many short-term bank credits are routinely rolled over it is difficult to make the distinction between short-term and long-term.
} 
changing extent of information asymmetries. When information is highly asymmetric and incomplete, investors will concentrate on projects and companies whose assets are tangible and whose operations are most transparent. Hence the disproportionate concentration of investors first on government securities and then on railways, canals, ports, public utilities and mining companies.

Similarly, when asymmetric information aggravates agency problems and issues of corporate control, investors will prefer debt instruments, the return on which is less closely tied to management actions than is the return on equity. Moreover, the creation of relatively concentrated equity stakes diminishes the collective action problem for equity holders by supplementing their holdings with non-voting debt. Hence the preference of pre-1914 investors for debt rather than equity.

Finally, Wilkins (1998) explains pre-1913 investors' reliance on free standing companies in terms of problems of information and risk. Free standing companies "were structured to solve the problem posed earlier: business abroad was risky; it was hard to obtain adequate and reliable information about firms in distant lands; returns were unpredictable; but there were clearly opportunities abroad; a company organized within the source-of-capital country, with a responsible board of directors, under source-ofcapital country law, to mobilize capital (and other assets) and to conduct the business in foreign countries could take advantage of the opportunities, while reducing transaction costs by providing a familiar conduit" (p.13, emphasis added).

By implication, greater breadth and international financial market today is to be understood in terms of the diminution of information asymmetries. We develop this argument further in the next section. 


\section{The Information Environment for International Investment}

Capital markets require information. Hence, the efficiency with which information is disclosed, transmitted, and processed can circumscribe the extent of the market. There is good reason to think, therefore, that changes in the facility with which these functions are carried out are a critical determinant of the scope of financial market integration. We consider changes over time under two headings: technological changes which aid information transmission and processing, and institutional changes which enhanced the generation and disclosure of economically meaningly financial information.

\subsection{Speed of Communication}

From this point of view, the key 19th-century breakthrough encouraging the international integration of financial markets was the invention of the telegraph. By reducing time delays in communicating information on prices, the telegraph reduced inter-market price differentials and facilitated the creation of unified markets within as well as across countries (Field 1992,1998). Michie (1988) documents how the telegraph linked the London Stock Exchange with the regional exchanges in the 1840s. By 1860, he argues, the UK for the first time effectively possessed a single securities market. A similar process took place in the United States, although there is debate over its timing. According to Davis (1962), U.S. financial integration did not occur until well after the Civil War. Bodenhorn (1995), however, provides convincing evidence that interregional and short-term interest rate differentials declined drastically well before the Civil War, suggesting that financial integration was facilitated by the advent of the telegraph, just as in the U.K.. Duboff (1983) documents, for example, how the advent of the telegraph led 
to the rapid expansion of futures trading in the the $1850 \mathrm{~s}$. A critical mass of futuresmarket transactions required the existence of continuous markets and the quick transmission of quotes (Williams 1987) ${ }^{29}$ For this too, a prerequisite was the existence of the telegraph.

For international markets, the breakthrough was the transatlantic cable, which came into operation in 1866 . (The telegraph girded the world by century's end. It reached Buenos Aires by 1878 , for example, and Tokyo by 1900 .) Before the cable, information could take up to three weeks to travel between London and New York (Garbade and Silber, 1978, p. 826). This meant that investors had to estimate the price of a security which would prevail three weeks hence based on information three weeks old. After the cable was opened, the delay dropped to one day. By 1914 the time for cable transmission was down to less than one minute. Garbade and Silber (1978) compare the London and New York prices of U.S. bonds four months before and four months after the cable. They find a significant decline in the mean absolute differences of price differentials.

The telephone was the other key breakthrough. By the 1870 s it was used to link British stock brokers and exchanges nation wide, and by 1900 the radio telephone linked Europe with North America. These advances in communications technology were especially important for encouraging investment in volatile securities issued by entities whose returns were sensitive to the business cycle or other short-term shocks.

The question arises whether improvements in communications technologies in recent years have had as great an impact. Surely the volume of information that can be

\footnotetext{
${ }^{29}$ In addition, the telegraph led to the development of wire services, first used by the Commercial and Financial Chronicle in 1865.
} 
transmitted through coaxial cables and the interface between the Internet and

telecommunications is an important element in the proliferation of securities markets in the past decade. Whether these developments are as important as the earlier ones is another question. There is reason to think otherwise. ${ }^{30}$

\subsection{Consequences of Asymmetric Information}

Asymmetric information can be a key barrier to the development of efficient financial markets within nations as well as globally. Among its consequences is adverse selection, the situation where firms most eager to borrow are bad credit risks. This leads to the "lemons" problem (Akerlof 1970, Stiglitz and Weiss 1981) where lending to all potential borrowers is curtailed. A further consequence is moral hazard, where the lender is subject to the risk that the borrower, having obtained the loan, engages in activity making it less likely to pay off the loan-the agency problem.

Asymmetric information has been invoked to explain many of aspects of the historical evolution of financial markets (Temin 1991, Raff and Lamoreaux 1995, Bordo and Sylla 1995). It explains why merchant and investment banks played a key role in financing industry in most industrializing countries, namely, that banks evolved methods to effectively monitor loans and to prevent free riding (Mishkin 1998). It explains the appearance of specialized publications such as The American Railroad Journal and Poor's Manual of the Railroads of the United States which provided investors information on railway securities. It explains the appearance of the Council of Foreign Bondholders and the English Association of American Bond and Shareholders, organized

\footnotetext{
${ }^{30}$ According to Garbade and Silber (1978), a comparison of the cost saving of the telegraph in the nineteenth century to the electronic linking of the New York with regional exchanges via a consolidated ticker tape in the 1970 s revealed that the early innovation far outweighed the latter one.
} 
to collect information on arrears on pubic as well as private securities (and to negotiate with debtors). It explains the development of investment trusts (the 19th century analog to modern mutual funds), to whom investors delegated information-gathering and analysis functions. It explains the appearance of insurance companies, in which households invested in response to the perception that these institutions had a comparative advantage in gathering information from far-flung regions. ${ }^{31}$

Asymmetric information explains why the first securities traded were fixedinterest government bonds secured by tax revenues and later bonds to finance infrastructure, often guaranteed by government tax revenues (see above). It explains why industrial securities, except in the case of well-known large companies, played a small role in industrial finance in the history of advanced countries (Mayer 1990). Thus, the first securities markets that developed in England (and the Netherlands) were for longterm government securities. These evolved once it became apparent that the nation state had sufficient fiscal authority to raise the taxes to service its debts and once private property (including claims on the government) was reasonably secure from arbitrary seizure (North and Weingast 1989). Markets also developed in the securities of the great chartered trading companies and later in quasi public transportation companies whose revenues were relatively transparent (Baskin 1988). But not until the mid-19th century did a market for corporate securities develop in England. The Companies Acts of 1844 and 1900 requiring that companies issue prospectuses and publish annual reports were breakthroughs in overcoming the public's fear of investing other than in securities with

\footnotetext{
31 A U.S. interegional market in mortgage backed securities issued by farm mortgage companies developed in the late nineteenth century. It collapsed in the 1890 s because the mortgage companies were unsuccessful in monitoring their loan agents (Snowden (1995)). National life insurance companies were however able to overcome the agency problem and after 1900 created a successful national market.
} 
fixed returns (Sylla and Smith 1995).

\subsection{Regulatory Responses}

While information barriers were partially surmounted by institutional innovations on the part of private entities such as investment banks, an important role was also played by government regulation requiring the production and dissemination of information through the adoption of public disclosure and standard accounting practices. Where government failed to contribute, market development lagged. According to Sylla and Smith (1995), the U.S. lagged the UK in the development of equities markets because it did not have effective corporate disclosure and public accounting requirements until the New Deal. In the absence of adequate disclosure, well-informed private investment bankers such as J.P. Morgan provided some of the relevent information and put their imprimatur on selected industrial securities. But the fact that they profited handsomely (DeLong, 1991)--in other words, that their quasi rents were not competed away--is evidence that this service was undersupplied.

The New Deal Securities Acts of 1933 and the Securities Exchange Act of 1934 making mandatory registration and disclosure for all securities listed on exchanges and requiring corporations to file annual reports were the breakthrough that allowed U.S. securities markets to blossom after World War II (Sylla and Smith, 1995). ${ }^{32}$ They reinforced initiatives by the Federal Reserve, which forced member banks to use standard accounting procedures to evaluate the securities eligible to be rediscounted, further

\footnotetext{
32 Specialists dispute the extent to which the SEC actually improved access to information. According to White (1998a, p.32), "Compared to the whole market, the average returns to investors from buying and holding newly issued securities were virtually the same before and after the New Deal. Only for unseasoned securities on the regional exchanges, where information costs may have been higher, is there the suggestion of mispricing before the New Deal. The variation in returns did fall, suggesting that risk was lowered. Yet this may also have reflected the shifting of securities to private placements."
} 
helping to overcome information asymmetry (White, 1998b).

\subsection{International Implications}

This approach can be extended to the international sphere. It explains why European portfolio investment in peripheral countries was initially concentrated in government securities in countries with colonial or Dominion status and where securities were denominated in gold and therefore received "the good housekeeping seal of approval" (Bordo and Rockoff 1996, Flandreau, LeCacheux and Zumer, 1998).

Subsequently, railroad securities, whose assets were tangible and which often had a government guarantee, became the primary object of British and other European investment. In contrast, portfolio investment in industrial securities outside the U.S. and Canada was limited because of lack of transparency, although British merchant banks specializing in marketing the securities of particular industries and companies could provide at least some of the requisite information. Rather than relying on stocks and bonds, foreign investors in many cases attempted to surmount information asymmetries and lack of transparency by establishing free standing companies investing directly in mineral extraction or plantations and later through direct investment and control of resources by multinational enterprises. ${ }^{33}$

Finally, of considerable importance in recent years in encouraging foreign investment and the proliferation of stock exchanges in many emerging markets has been the reduction and elimination of government regulations, the securing of private property rights including the ability to enforce debt contracts, protection against arbitrary seizure

\footnotetext{
33 See Carlos and Lewis (1995), however, who show that in the case of Canada, even in the late nineteenth century, where information was believed to be good, British investors were burned when investing in a number of railroad securities.
} 
and nationalization of foreign assets, the privatization of national industries and the elimination of capital controls. These structural innovations are being introduced against a background of macroeconomic stabilization which has reduced high and variable inflation and hence the country risk premium, and fiscal reform which secures the tax revenues necessary to service and make more marketable government debt.

For all these reasons, then, while net flows as a percentage of GNP a century ago may have been comparable to those of the present day, the breadth of international capital market integration is greater today.

\section{Conclusion}

The evidence surveyed here reveals that pre-1914 markets for a relatively narrow range of homogeneous assets (government securities, railroad bonds) were as tightly integrated as in the present day. At the same time, information asymmetries may have prevented the range and variety of international investments and breadth of capital market integration that we see today. To be sure, market participants developed institutions to attenuate these information problems, notably free standing companies, 'classic' multinational enterprises, and market-making merchant and investment banks (such as Barings and J.P. Morgan), but while these "institutional substitutes" diminished information problems, they far from eliminated them. Over recent decades, the informational obstacles to financial transactions have been further lessened, and in consequence a much broader range of securities is traded internationally. Within the advanced countries this reflects two sets of forces: further institutional innovation in private markets, and government intervention requiring that participants in domestic and 
international markets meet accepted standards of financial accounting, reporting and disclosure. $^{34}$

Turning to the real side of the economy, the 19th century heyday of international lending reflected a configuration of favorable forces: the culmination of the industrial revolution, global peace (relatively speaking at least), the Pax Britannica, a low ebb in economic nationalism, and an ideology of minimal interference with the operation of market forces (Bordo 1998, Eichengreen 1992, 1996). These conditions provided a favorable framework for the capital transfers that flowed from the Old World to the New. Today we may be experiencing many similar sorts of forces: relative peace after the end of the "second thirty years war" and the Cold War, a Pax Americana, another low ebb in economic nationalism, and a return to less government intervention in markets, both domestically and internationally. This has set the stage for the deregulation of financial markets and inaugurated a second era of globalization. Where the first era globalized the benefits of the industrial revolution, the second is doing the same for the new revolution in information and communications technologies.

\footnotetext{
${ }^{34}$ Emerging markets, in addition to adopting the changes occurring in the developed countries, have had to overcome the effects of unstable government, the absence of secure property rights, erratic macroeconomic policies, and less-than-transparent public finances. This process of doing so is accelerating under pressure to gain the access to the international capital needed to speed the process of development.
} 


\section{References}

Akerlof, George (1970). "The Market for Lemons: Quality Uncertainty and the Market Mechanism." Quarterly Journal of Economics. Vol 84. Pp 488-500.

Bairoch, Paul, and Richard Kozul-Wright (1996). "Globalization Myths: Some Reflections on Integration, Industrialization, and Growth in the World Economy." United Nations Conference on Trade and Development. Discussion Paper No. 113 (March).

Bank for International Settlements (1997). "Central Bank Survey of Foreign Exchange Market Activity.” Basle: BIS.

Baskin, Jonathan B. (1988). “The Development of Corporate Financial Markets in Britain and the United States, 1600-1914: Overcoming Asymmetric Information." Business History Review. Vol. 62. (Summer) pp. 197-237.

Bayoumi, Tamim (1990). “Saving-Investment Correlations: Immobile Capital, Government Policy, or Endogenous Behavior?” IMF Staff Papers, Vol. 37. No. 2. (June) pp. 360-387.

Bayoumi, Tamim and Barry Eichengreen (1996). "The Stability of the Gold Standard and the Evolution of the International Monetary System" in Tamim Bayoumi, Barry Eichengreen, and Mark Taylor (eds.) Modern Perspectives on the Gold Standard, Cambridge: Cambridge University Press.

Bloomfield, Arthur I. (1963). Short-Term Capital Movements Under the Pre-1914 Gold Standard. Princeton, NJ: Princeton Studies in International Finance. No. 11.

Bloomfield, Arthur I. (1968). Patterns of Fluctuation in International Finance Before 1914, Princeton Studies in International Finance. No. 21. 
Bodenhorn, Howard (1992). "Capital Mobility and Financial Integration in Ante-Bellum America." Journal of Economic History. Vol. 52. pp. 585-610.

Bodenhorn, Howard (1995). "A More Perfect Union: Regional Interest Rates in the United States, 1880-1960.” in Michael D. Bordo and Richard Sylla, eds. AngloAmerican Financial Systems: Institutions and Markets in the Twentieth Century. New York: Irwin Professional Publishing. pp. 415-454.

Bordo, Michael D. (1986). "Financial Crises, Banking Crises, Stock Market Crashes and the Money Supply: Some International Evidence, 1870-1933.” in Forrest Capie and Geoffrey Wood, eds. Financial Crises and the World Banking System. London: Macmillan.

Bordo, Michael D. (1993). "The Bretton Woods International Monetary System: A Historical Overview." in Michael D. Bordo and Barry Eichengreen, eds. A Retrospective on the Bretton Woods System: Issues for International Monetary Reform. Chicago: University of Chicago Press.

Bordo, Michael D., and Hugh Rockoff (1996). "The Gold Standard as a Good Housekeeping Seal of Approval." Journal of Economic History. Vol. 56 (June) pp. 389-428.

Bordo, Michael D., and Kornelia Krajnyak (1997). "Globalization in Economic Perspective.” World Economic Outlook. Annex I. IMF. May pp. 162-171. Bordo, Michael D., and Ronald MacDonald (1997). "Violations of the 'Rules of the Game' and the Credibility of the Classical Gold Standard, 1886-1914.” NBER Working Paper. No. 6115. July.

Bordo, Michael D., and Ronald MacDonald (1988) "The Interwar Gold Exchange 
Standard: A Credible System?" (Mimeo) Strathclyde University.

Bordo, Michael D., and Anna J. Schwartz (1997). "Monetary Policy Regimes and

Economic Perfomance: the Historical Record." NBER Working Paper No. 6201 (September).

Bremnes, Helge, Oystein Gjerde, and Frode Saettem (1997). "A Multivariate

Cointegration Analysis of Interest Rates in the Eurocurrency Market." Journal of International Money and Finance. Vol. 16, No. 5. pp. 767-778.

Calomiris, Charles, and Glenn R. Hubbard (1996). "International Adjustment Under the Classical Gold Standard: Evidence for the U.S. and Britain, 1879-1914" in Tamim Bayoumi, Barry Eichengreen and Mark P. Taylor, eds. Modern Perspectives on the Gold Stadard. Cambridge: Cambridge University Press.

Carlos, Ann M., and Frank D. Lewis (1995). "Foreign Financing of Canadian Railroads: the Role of Information." in Michael D. Bordo and Richard Sylla, eds. AngloAmerican Financial Systems: Institutions and Markets in the Twentieth Century. New York: Irwin Professional Publishing. pp. 415-454.

Coakley, J., F. Kulasi and R. Smith (1998), "The Feldstein-Horioka Puzzle and Capital Mobility: A Review," International Journal of Finance and Economics 3, pp.169194.

Cochrane, John (1988). "How Big is the Random Walk in GNP?" Journal of Political Economy, 98 (June). pp. 501-518.

Davis, Lance E. (1965). “The Investment Market, 1870-1914: The Evolution of a National Market.” Journal of Economic History. 25. pp. 355-99.

Devries, Margaret Garrison (1986). The IMF in a Changing World, 1945-85. 
Washington: International Monetary Fund.

Delong J., Bradford (1991). "Did Morgan's Men Add Value?" in Peter Temin, ed. Inside the Business Enterprise: Historical Perspectives on the Use of Information.

Chicago: University of Chicago Press. pp. 205-236.

DeLong, J. Bradford et al. (1987), “Economic Consequences of Noise Traders,” NBER Working Paper no. 2395 (October).

Duboff, Richard (1983). "The Telegraph and the Structure of Markets in the United States, 1845-1890." in Paul Uselding, ed. Research in Economic History. Volume 8. Greenwich Ct: JAI Press. pp. 253-78.

Eichengreen, Barry (1990). "Trends and Cycles in Foreign Lending." in Horst Siebert, ed. Capital Flows in the World Economy. Tubingen: Mohr.

Eichengreen, Barry (1992). Golden Fetters. Oxford: Oxford University Press.

Eichengreen, Barry (1996). Globalizing Capital: A History of the International Monetary System. Princeton: Princeton University Press.

Feldstein, Martin, and Charles Horioka (1980). "Domestic Saving and International Capital Flows.” Economic Journal. Vol 90. (June) pp. 314-29.

Field, Alexander J. (1992). "The Magnetic Telegraph, Price and Quantity Data, and the New Management of Capital." Journal of Economic History. Vol 52. No. 2 (June) pp. $401-413$.

Field, Alexander J. (1998). "The Telegraphic Transmission of Financial Asset Prices and Orders to Trade: Implications for Economic Growth, Trading Volume, and Securities Market Regulation." (mimeo) Santa Clara University. February. Fishlow, Albert (1985). "Lessons From the Past: Capital Markets During the 19th 
Century and the Interwar Period." International Organization. 39. No. 3.

Flandreau, Marc (1998). "Caveat Emptor: Dealing With Sovereign Risk in the Age of Globalization, 1871-1913.” Ecole des Hautes Etudes en Sciences Sociale, Paris. (mimeo) April.

Flandreau, Marc; Jacque Le Cacheux and Frederic Zumer (1998). "Stability Without a Pact? Lessons From the European Gold Standard, 1880-1914." Economic Policy Volume 26 (April) pp. 115-162.

Garbade, Kenneth D., and William L. Silber. "Technology, Communication and the Performance of Financial Markets: 1840-1975." Journal of Finance Vol. XXXIII No. 1 (June) pp. 819-832.

Hatton, Timothy J., and Jeffrey G. Williamson (1998). The Age of Mass Migration: Causes and Economic Impact. New York: Oxford University Press. International Monetary Fund. International Financial Statistics. Various years. Jones, Matthew T., and Maurice Obstfeld (1997). "Saving, Investment, and Gold: A Reassessment of Historical Current Account Data.” NBER Working Paper. No. 6103. July.

Kindleberger, Charles (1989). Manias, Panics, and Crashes. Revised Edition. New York: Basic Books.

Kregel, Jan (1994), “Capital Flows: Globalization in Production and Financing Development" UNCTAD Review.

Lamoreaux, Naomi R., and Daniel M.G. Raff (1995), eds. Coordination and Information: Historical Perspectives on the Organization of Enterprise. Chicago: University of Chicago Press. 
Lothian, James R. (1995). "Capital Market Integration and Exchange-Rate Regimes in Historical Perspective." (mimeo) Fordham University.

Marston, Richard C. (1993). "Interest Differentials Under Bretton Woods and the PostBretton Woods Float: the Effects of Capital Controls and Exchange Risk.” in Michael D. Bordo and Barry Eichengreen, eds. A Retrospective on the Bretton Woods System: Lessons for International Monetary Reform. Chicago: University of Chicago Press. pp. 515-538.

Marston, Richard C. (1995). International Financial Integration: A Study of Interest Differentials Between the Major Industrial Countries. Cambridge: Cambridge University Press.

Mayer, Colin (1990). "Financial Systems, Corporate Finance, and Economic Development." in R. Glenn Hubbard, ed. Asymmetric Information, Corporate Finance, and Investment. Chicago: University of Chicago Press. pp. 307-332. McKinnon, Ronald I. (1988). “An International Gold Standard Without Gold.” Cato Journal. 8 (Fall) pp. 351-73.

Michie, Ranald C. (1988). The New York and London Stock Exchanges, 1850-1914. London: Allen and Unwin.

Mishkin, Frederic S. (1998). "International Capital Movements, Financial Volatility and Financial Instability." NBER Working Paper No. 6390. January.

Neal, Larry (1990). The Rise of Financial Capitalism: International Capital Markets in the Age of Reason. Cambridge: Cambridge University Press.

Nurkse, Ragnar (1944). International Currency Experience. Geneva: League of Nations. North, Douglas, and Barry Weingast (1989). "Constitution and Commitment: Evolution 
of Institutions Governing Public Choice." Journal of Economic History. 69(4) (December). pp. 803-837.

Obstfeld, Maurice (1995). "International Capital Mobility in the 1990s." in Peter B. Kenen, ed. Understanding Interdependence: The Macroeconomics of the Open Economy. Princeton: Princeton University Press.

Obstfeld, Maurice, and Alan Taylor (1998). "The Great Depression as a Watershed: International Capital Mobility over the Long-Run.” in Michael D. Bordo, Claudia Goldin and Eugene N. White, eds. The Defining Moment: The Great Depression and the American Economy in the Twentieth Century. Chicago: University of Chicago Press. pp. 353-402.

O'Rourke, Kevin H., and Jeffrey G. Williamson (1998). Globalization and History: the Evolution of a 19th Century Atlantic Economy. Cambridge: MIT Press (forthcoming).

Royal Institute of International Affairs (1937). The Problem of International Investment. London: Oxford University Press.

Snowden, Kenneth A. (1995). "The Evolution of Interegional Mortgage Lending Channels, 1870-1940: The Life Insurance-Mortgage Company Connection." in Naomi R. Lamoreaux and Daniel M.G. Raff, eds. Coordination and Information: Historical Perspectives on the Organization of Enterprise. Chicago: University of Chicago Press. pp. 209-246.

Stiglitz, Joseph F., and A. Weiss (1981). "Credit Rationing in Markets with Imperfect Information." American Economic Review. Vol 71. pp. 343-410.

Sussman, Nathan and Yishay Yateh (1998). "Institutions, Economic Growth, and Country 
Risk: Evidence from Japanese Government Debt in the Meiji Period.” Jerusalem. Hebrew University (mimeo). February.

Sylla, Richard, and George D. Smith (1995). "Information and Capital Market Regulation in Anglo-American Finance." in Michael D. Bordo and Richard Sylla, eds. AngloAmerican Financial Systems: Institutions and Markets in the Twentieth Century. New York: Irwin Professional Publishing. pp. 179-216.

Taylor, Alan M. (1992). “Argentine Economic Growth in Comparative Perspective.” Ph.D. Dissertation. Harvard University.

Taylor, Alan M. (1994). "Domestic Saving and International Capital Flows Reconsidered." NBER Working Paper No. 4892. October.

Taylor, Alan M. (1996). "International Capital Mobility in History: The SavingInvestment Relationship." NBER Working Paper No. 5743. September.

Taylor, Alan M. (1997). “Argentina and the World Capital Market: Saving, Investment, and International Capital Mobility in the Twentieth Century." NBER Working Paper No. 6302. December.

Temin, Peter (1991). ed. Inside the Business Enterprise: Historical Perspectives on the Use of Information. Chicago: University of Chicago Press.

Twomey, Michael J. (1998). "Patterns of Foreign Investment in the Third World in the Twentieth Century." University of Michigan, Dearborn. (mimeo) March.

United Nations (1949). International Capital Movements During the Inter-War Period. Lake Success, NY.

White, Eugene N. (1998a). "Banking and Finance in the Twentieth Century" in Stanley Engerman and Robert Gallman, eds. Cambridge Economic History of the United 
States. New York. Cambridge University Press (forthcoming).

White, Eugene N. (1998b). "Were Banks Special Intermediaries in Late Ninteteenth Century America?” Federal Reserve Bank of St. Louis Review. (forthcoming). Wilkins, Mira (1998). "Conduits for Long-Term Investment in the Gold Standard Era." Florida International University. (mimeo) March.

Williams, Jeffrey (1987). "Futures Markets: A Consequence of Risk Aversion or Transaction Costs?" Journal of Political Economy. Vol 95, No. 5 (October) pp. $1000-1023$.

Zevin, Robert (1992). “Are World Financial Markets More Open? If So, Why and With What Effects?" in Tariq Banuri and Juliet B. Schor, eds. Financial Openness and National Autonomy. Oxford: Clarendon Press. pp. 43-83. 


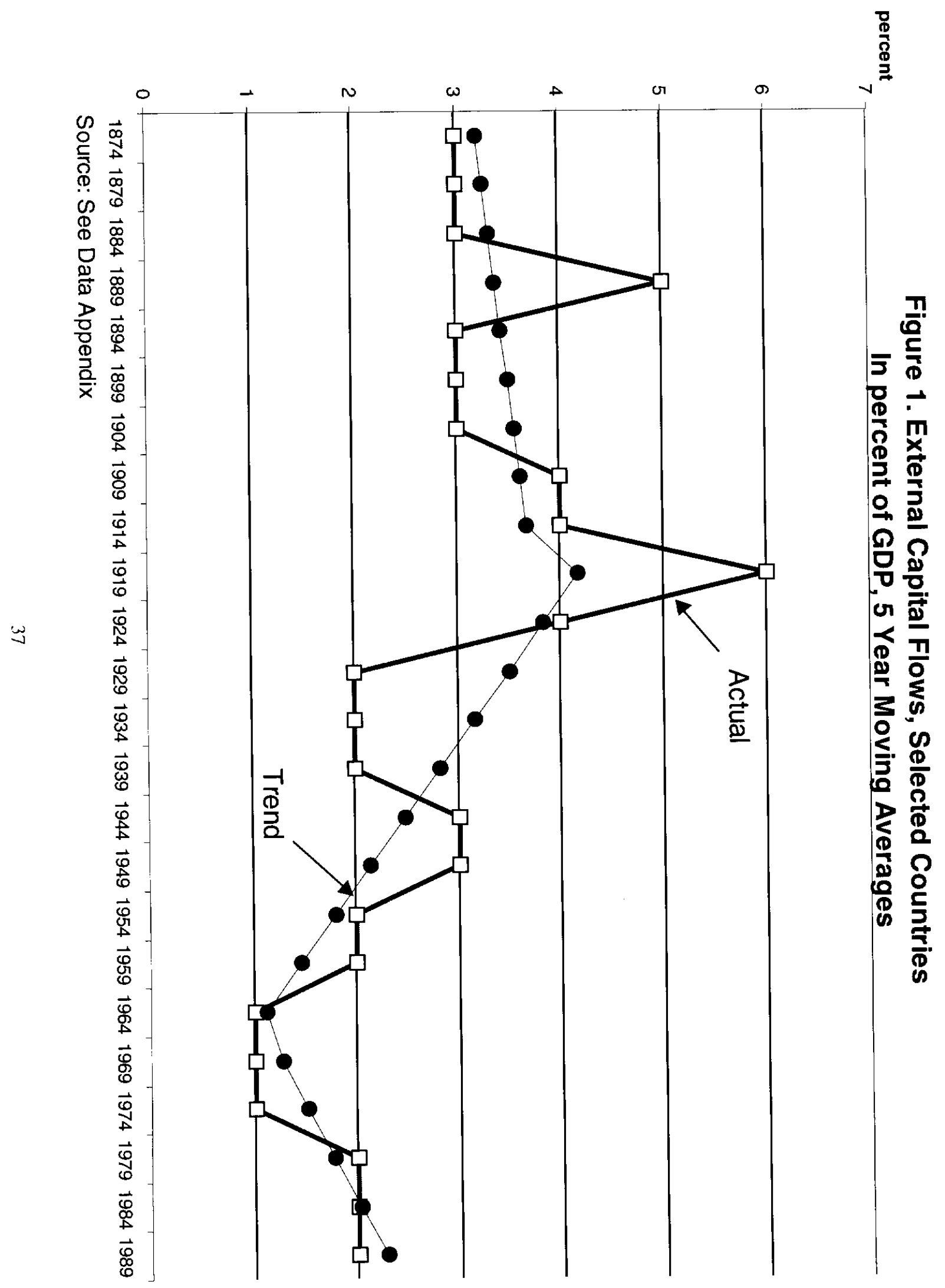


Figure 2. Ratio of the Current Account to GDP, Selected Major Countries
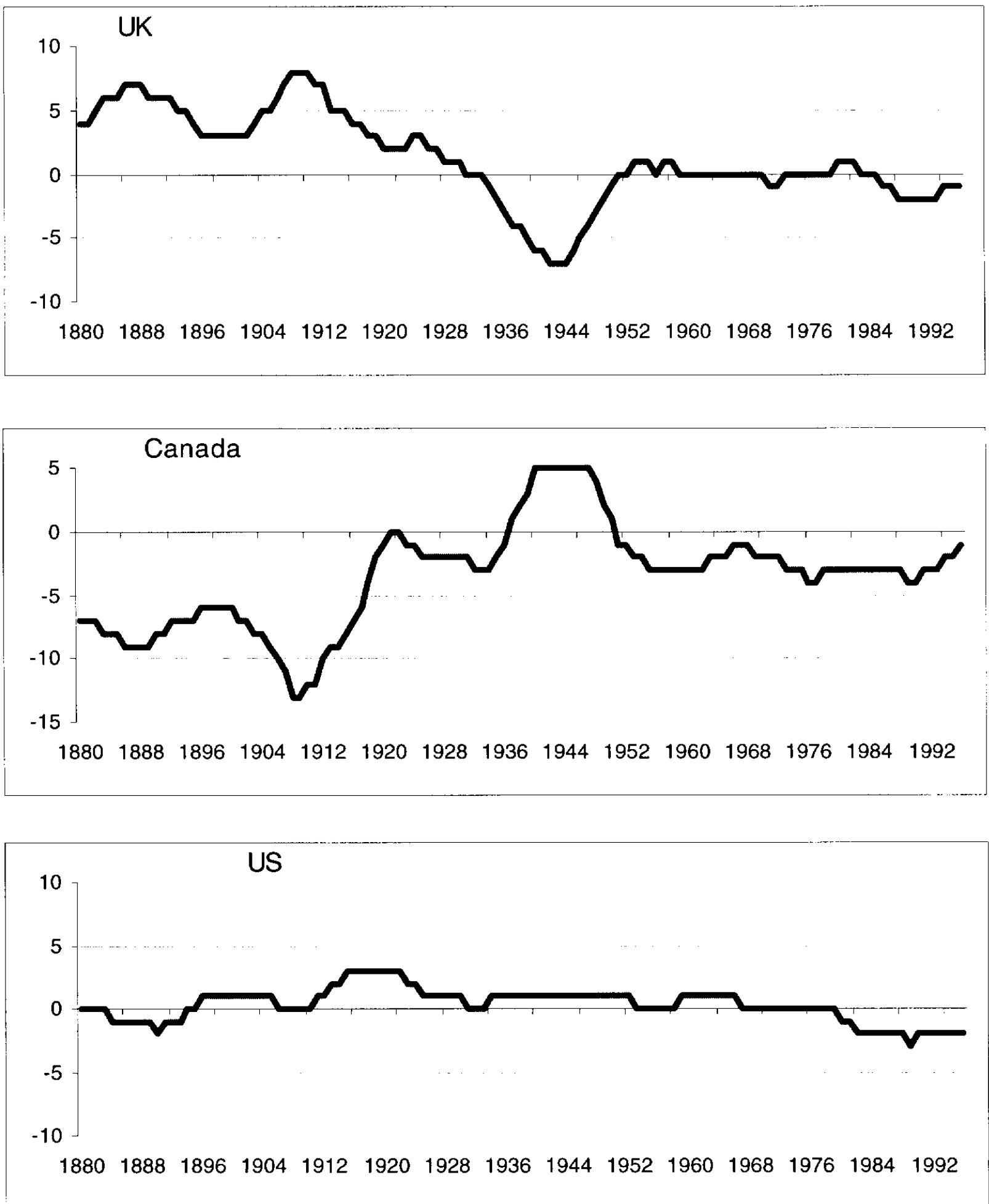

Source: See Data Appendix 


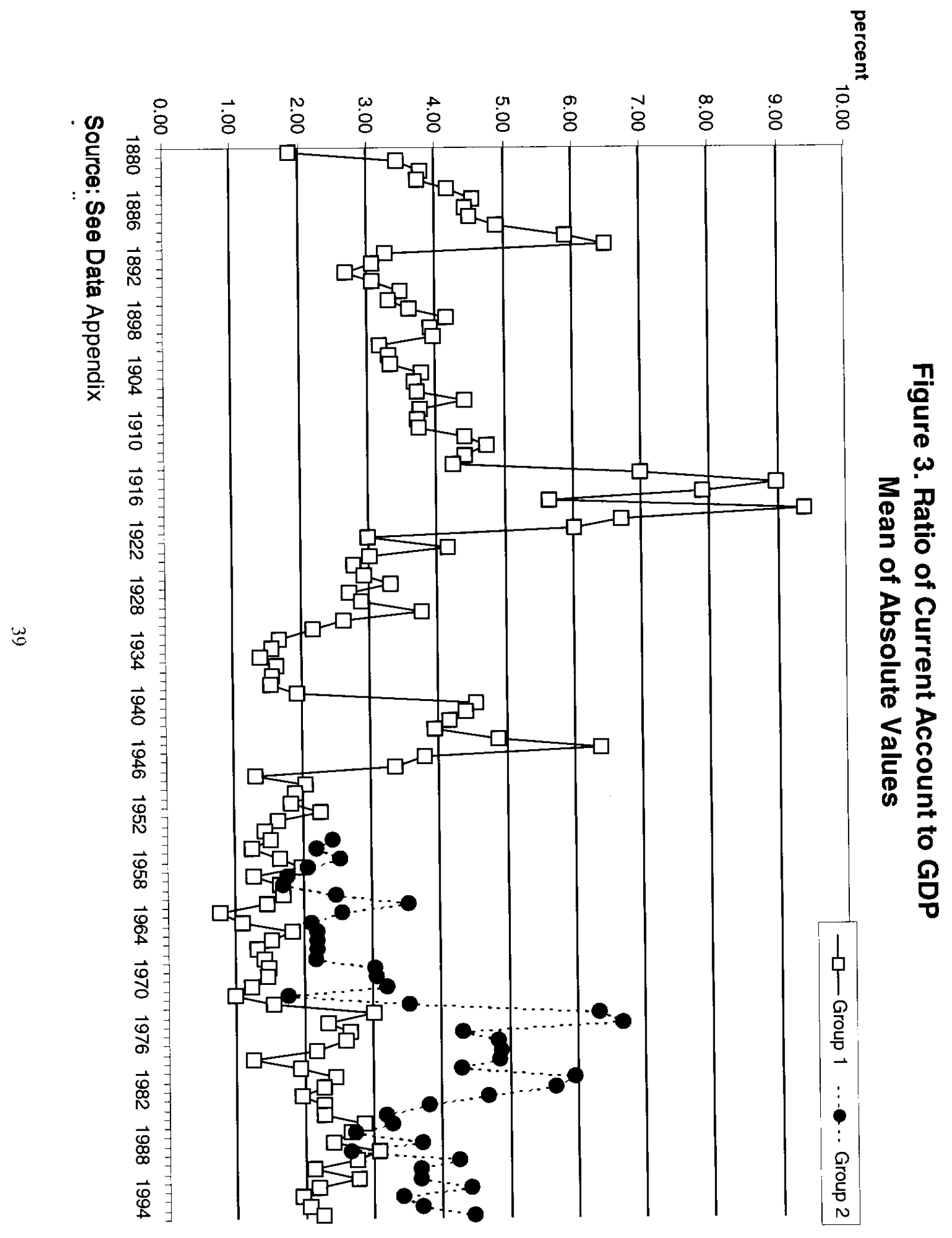




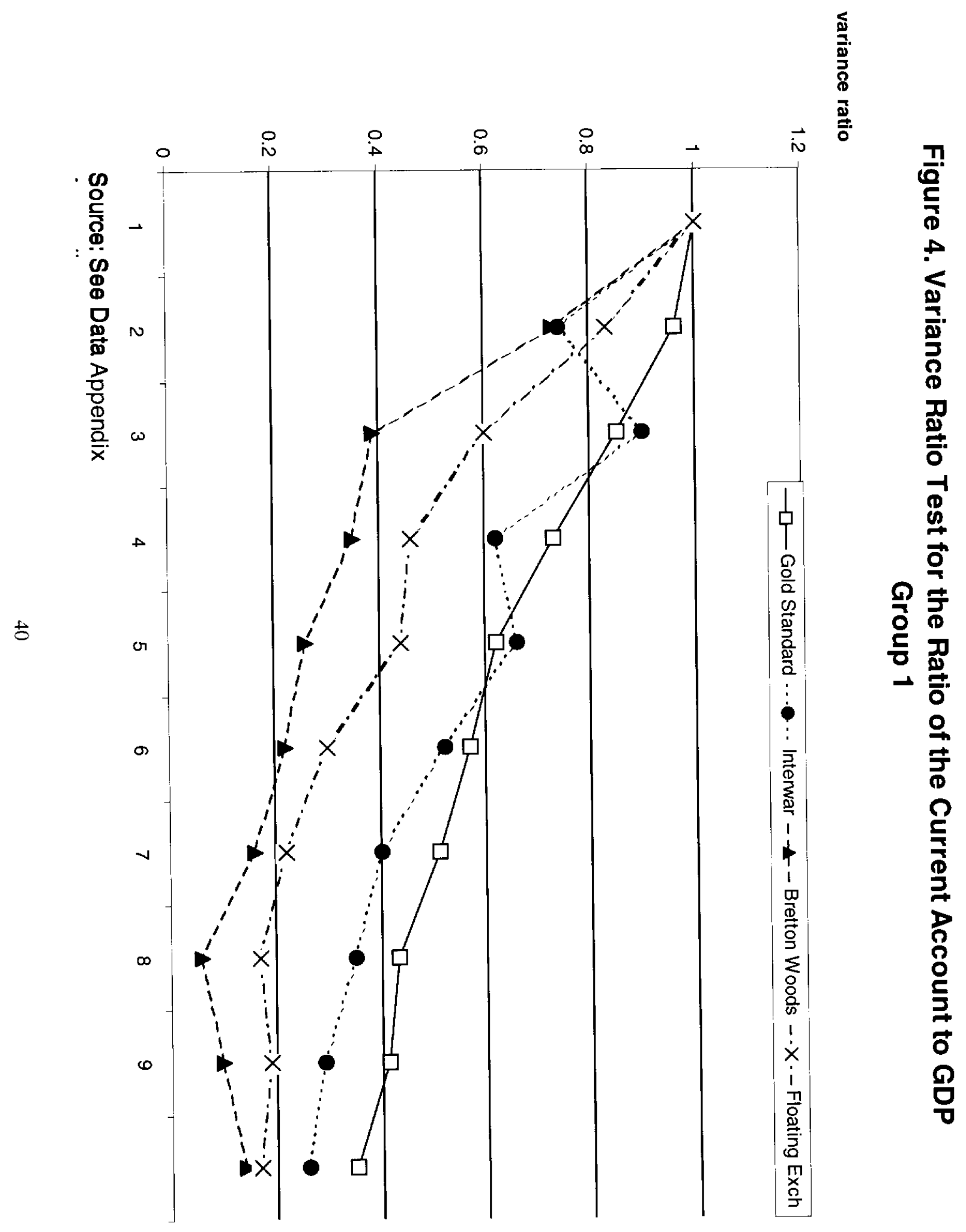




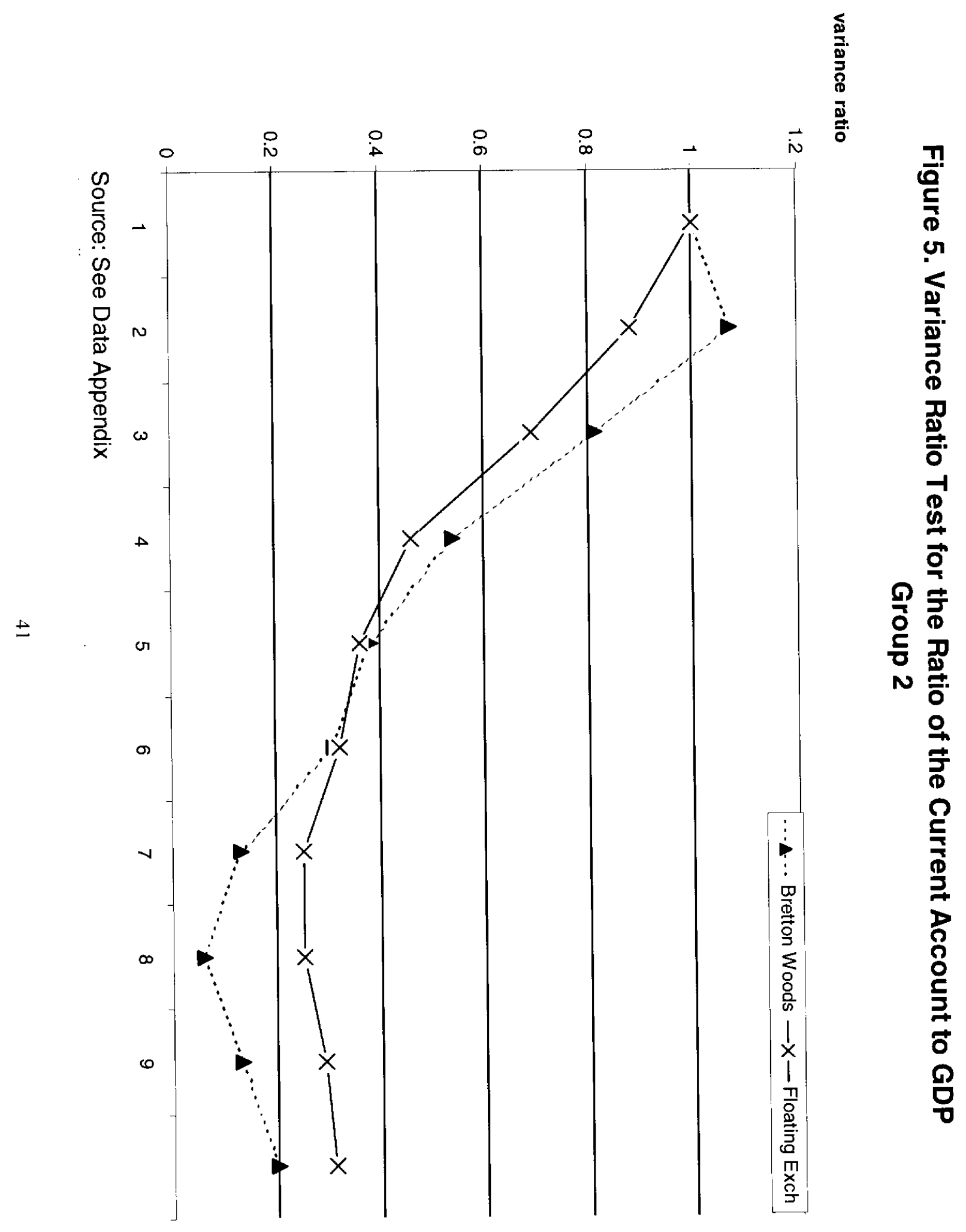




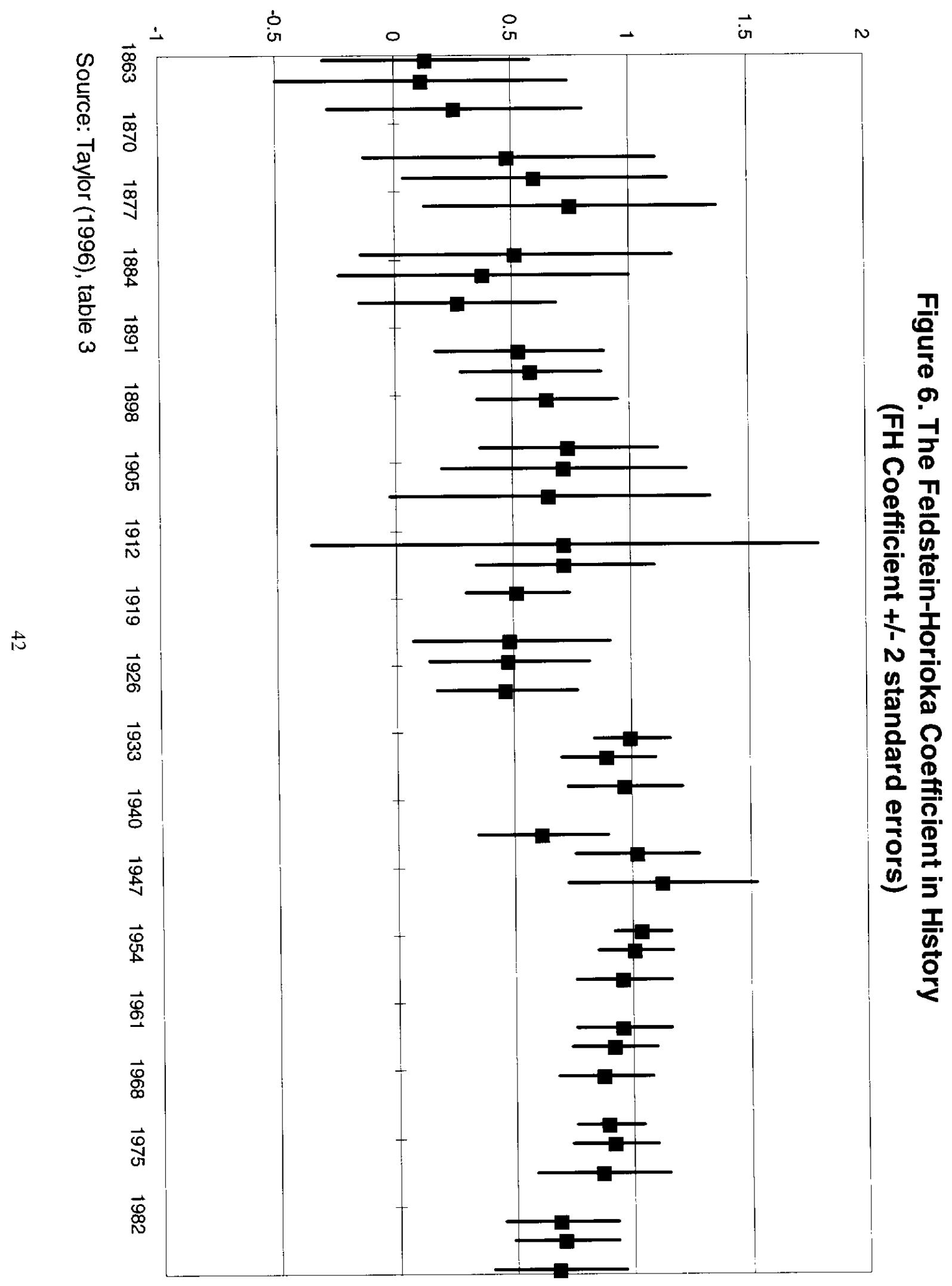




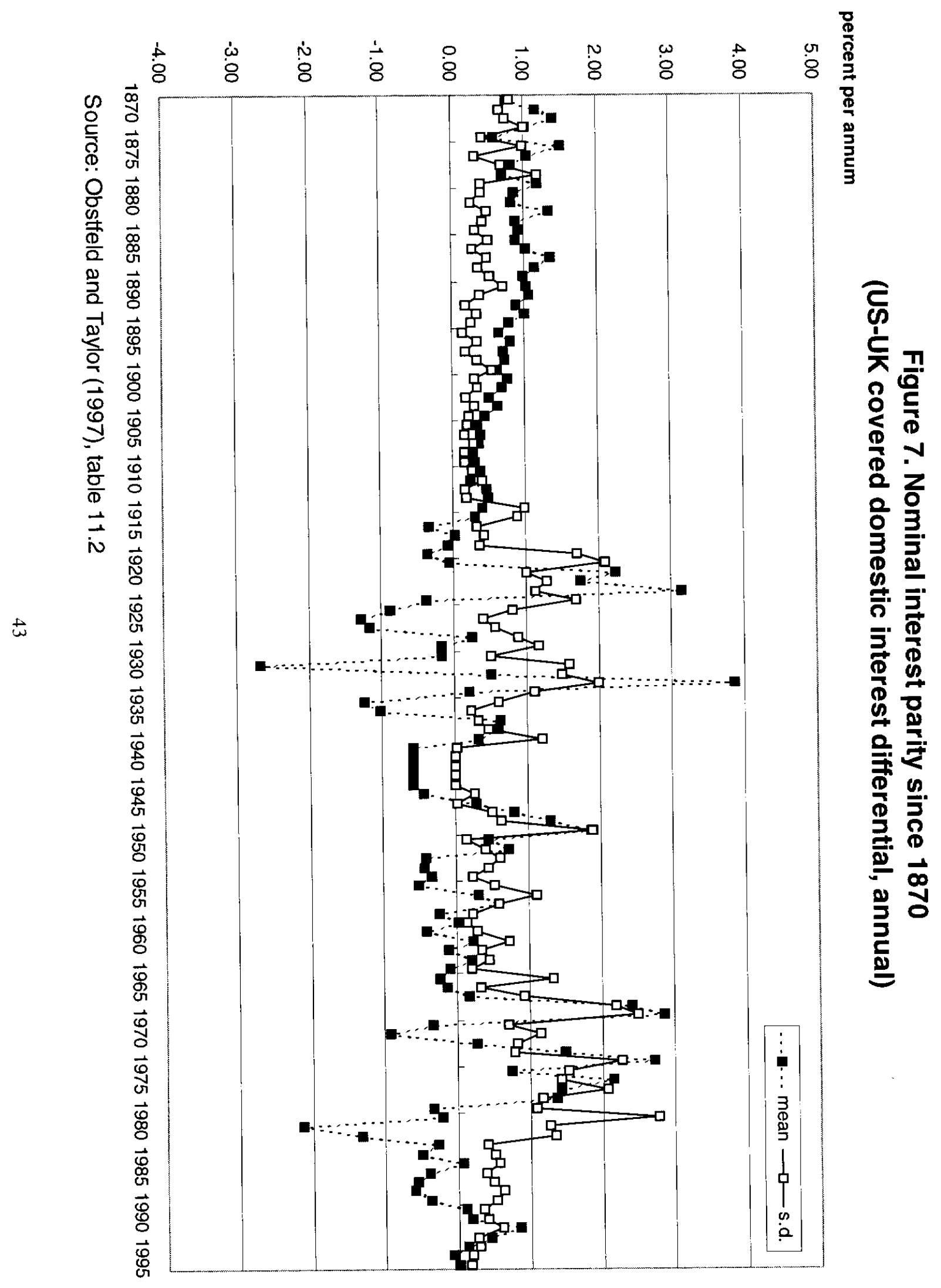




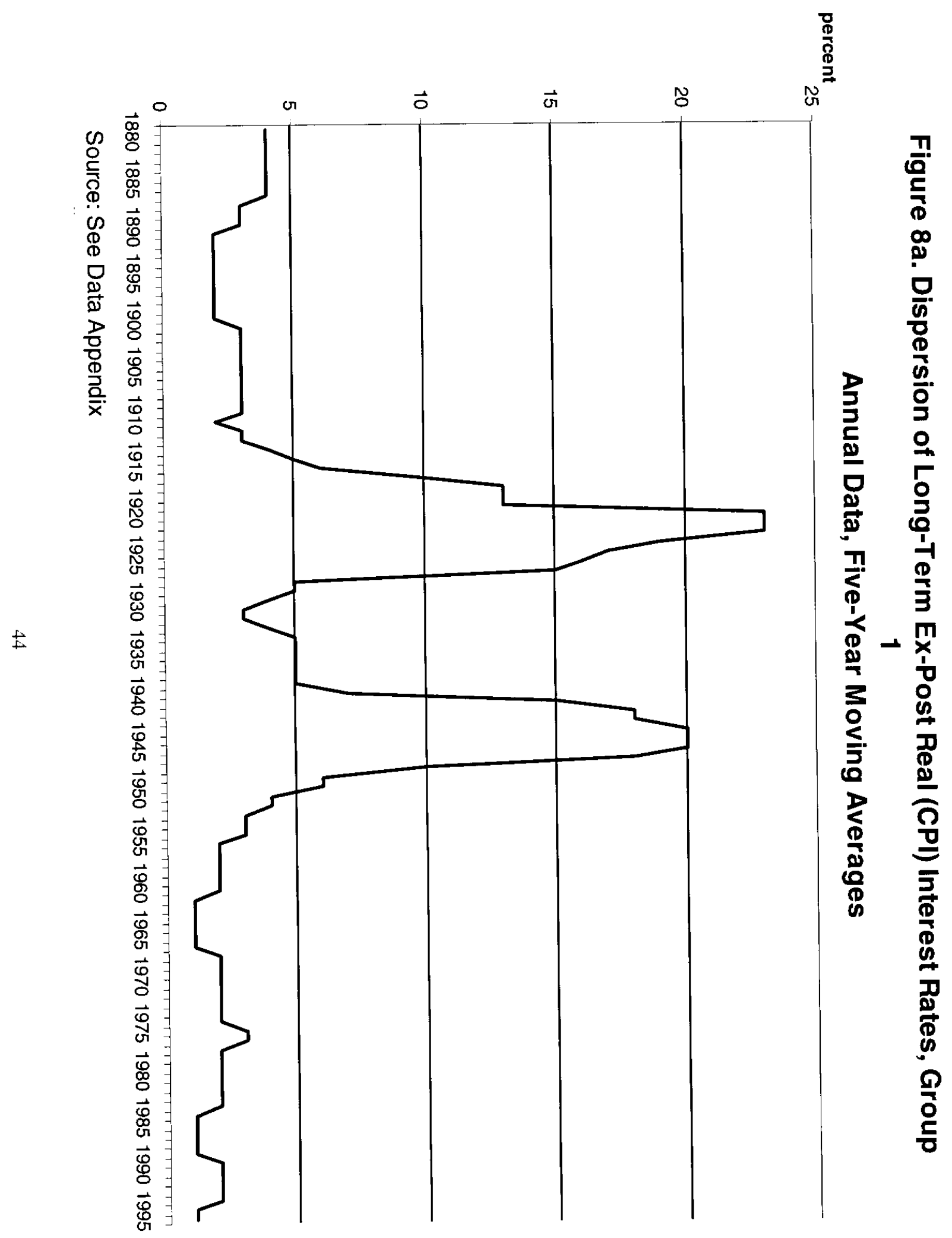




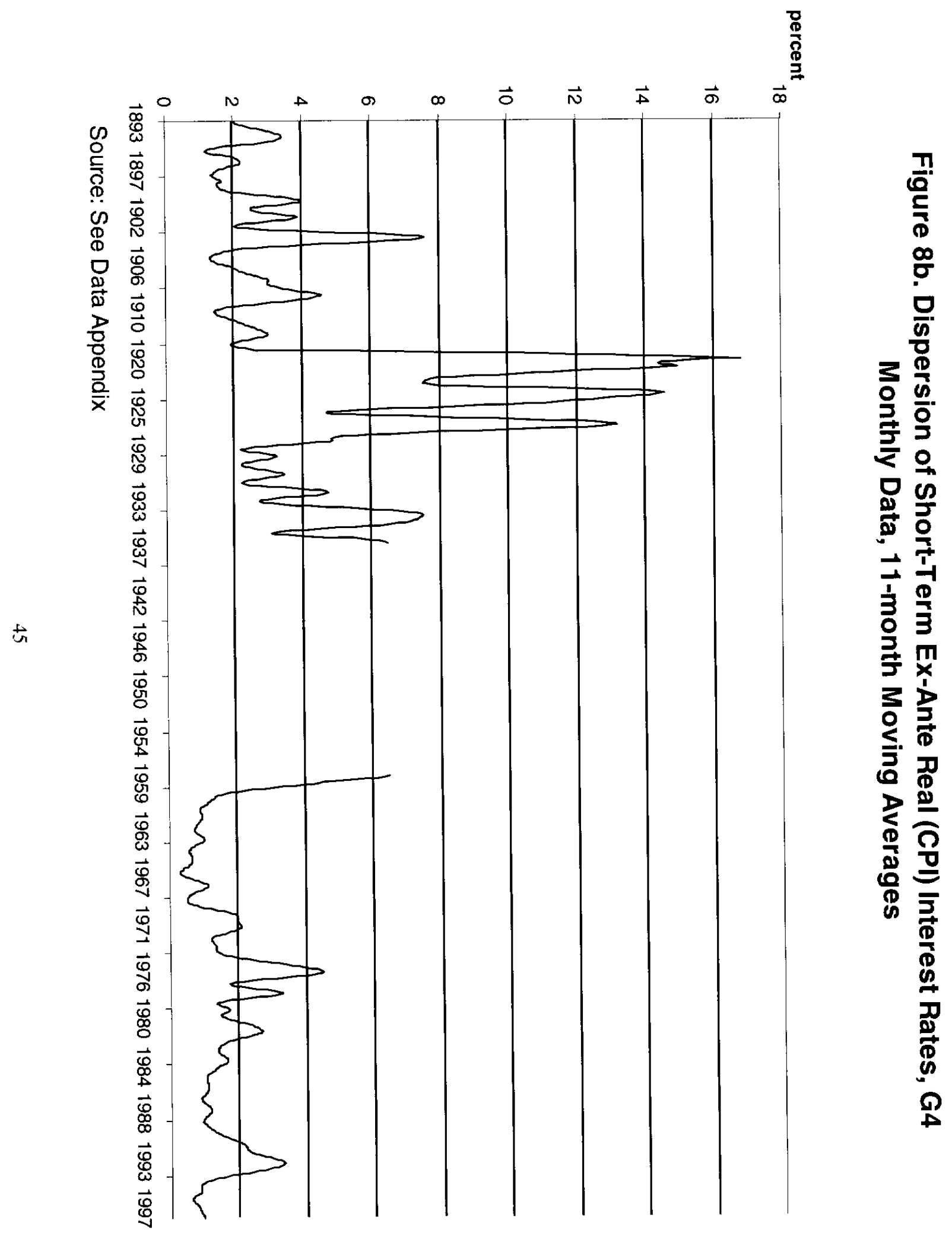


Figure 9. Short-Term Nominal Interest Rates

\section{1 month Moving Averages}
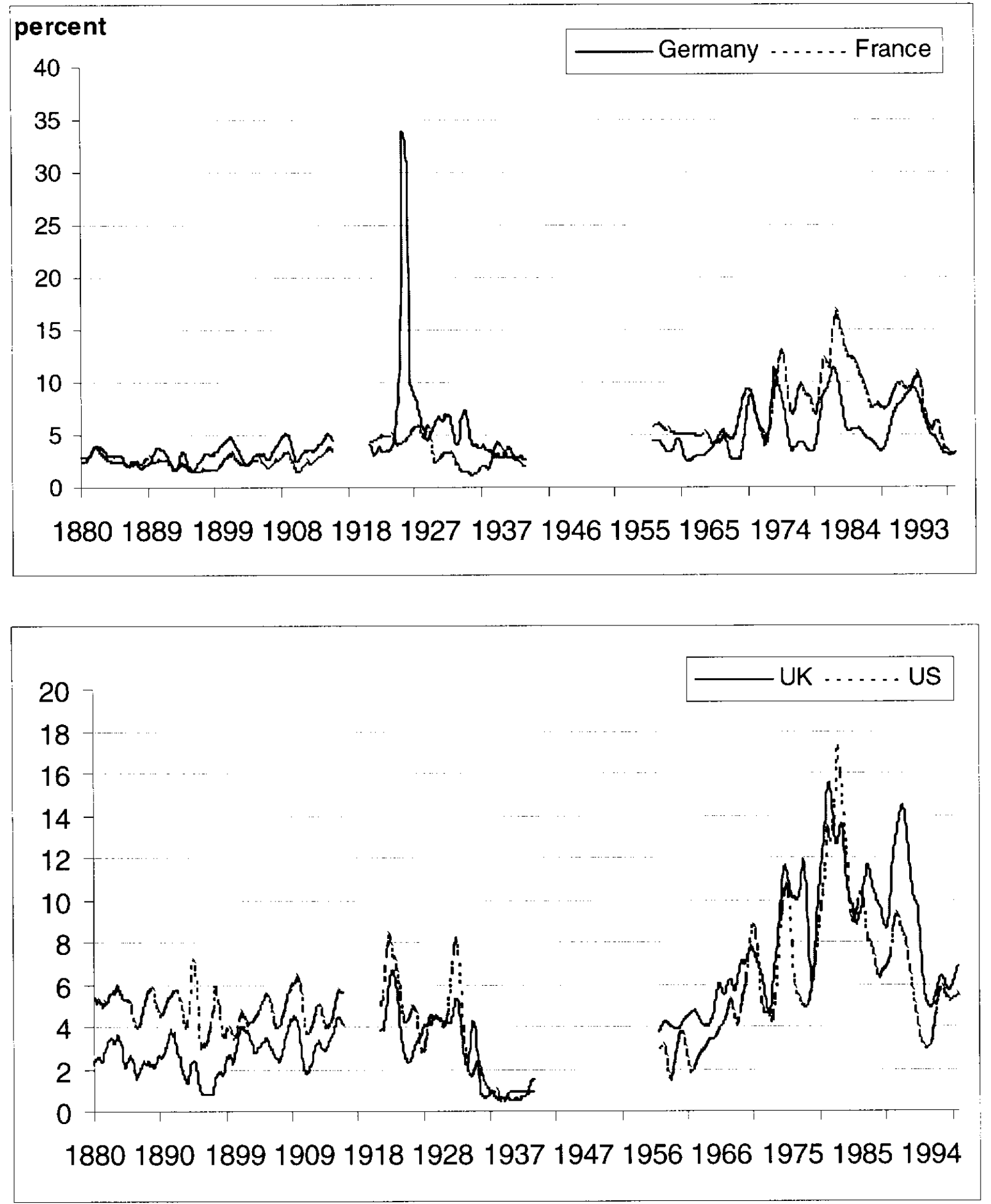

Source: See Data Appendix 
Figure 10. Short-Term Real Interest Rates

11 month Moving Averages

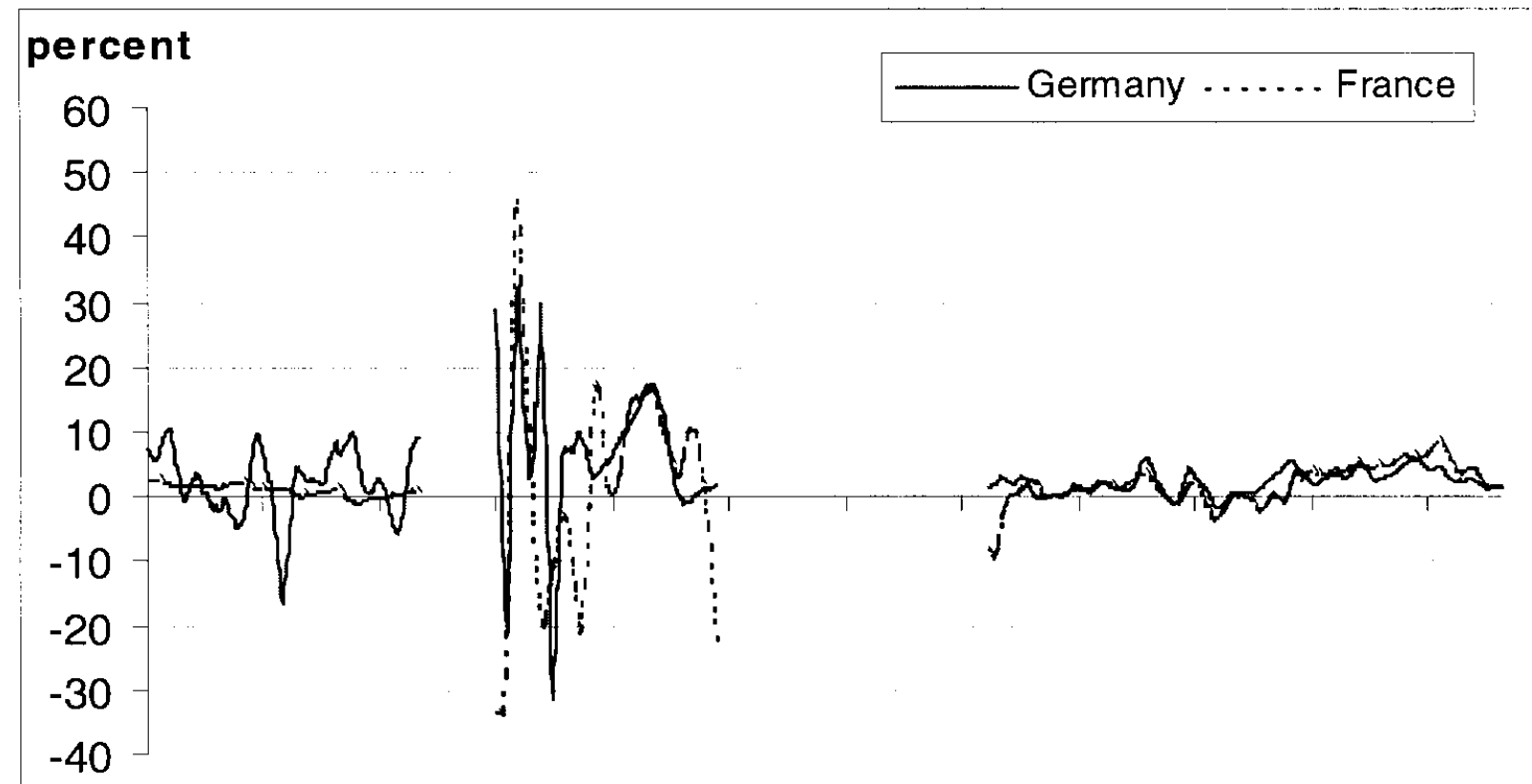

1893190219101919192719361944195319611970197819871995

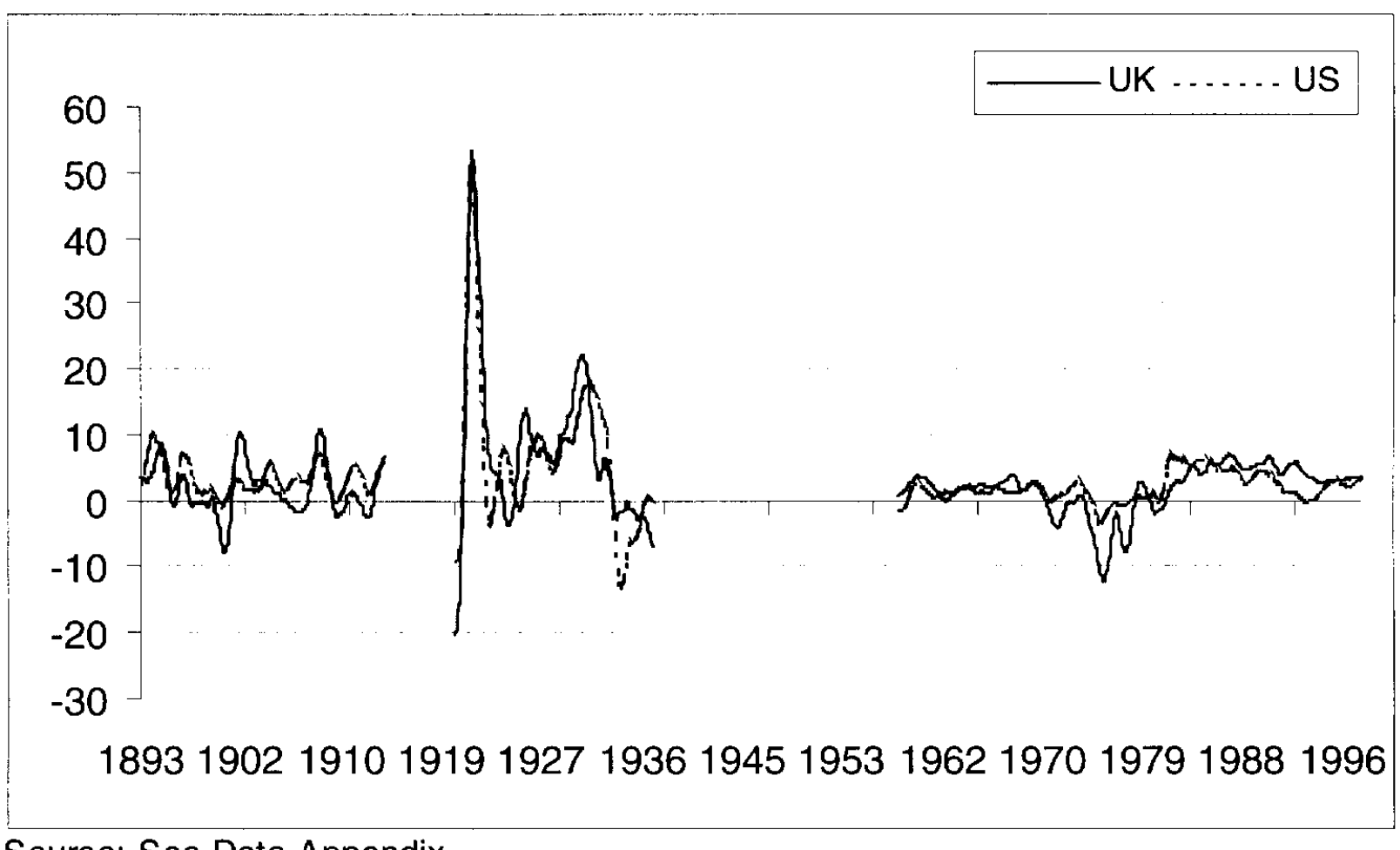

Source: See Data Appendix 


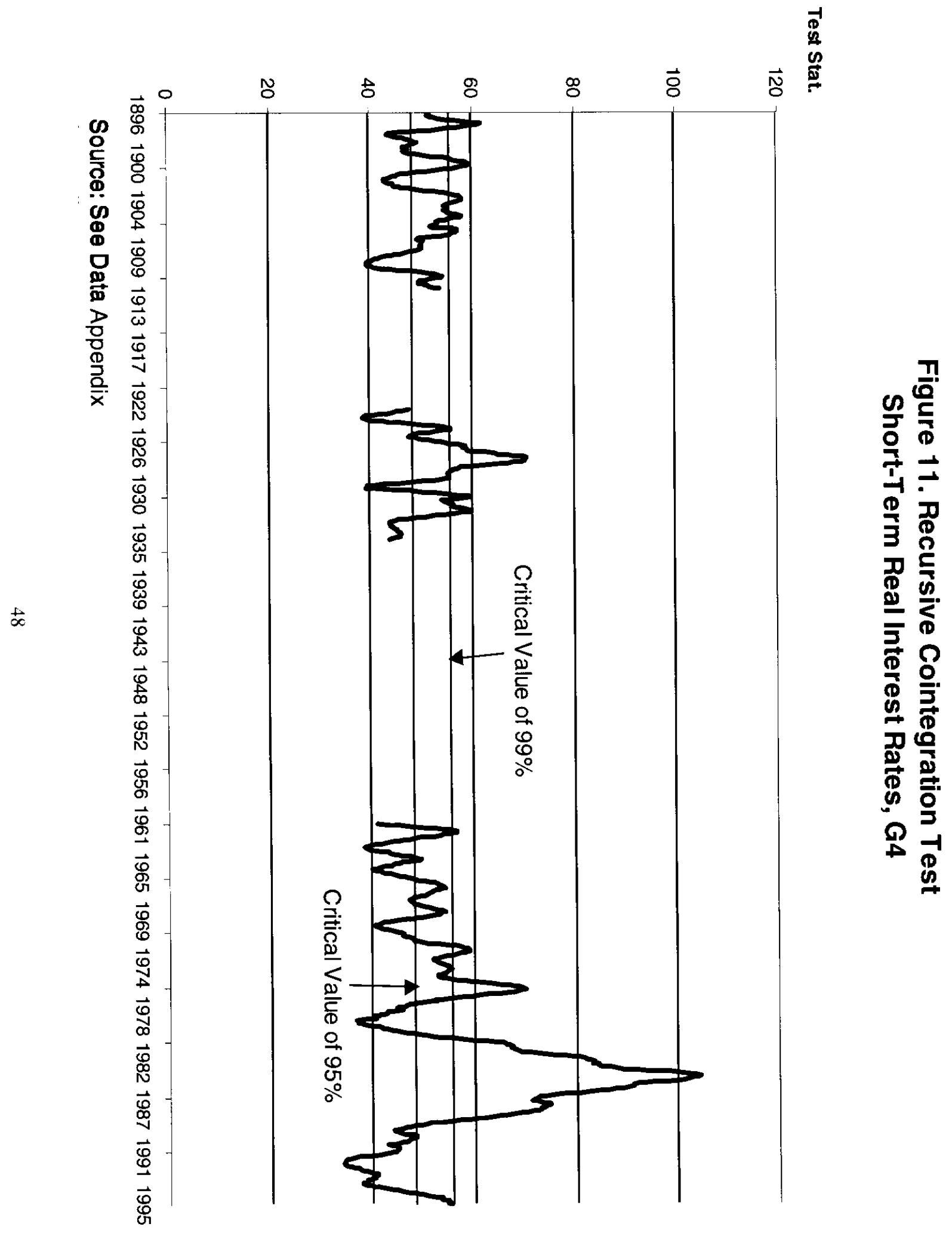




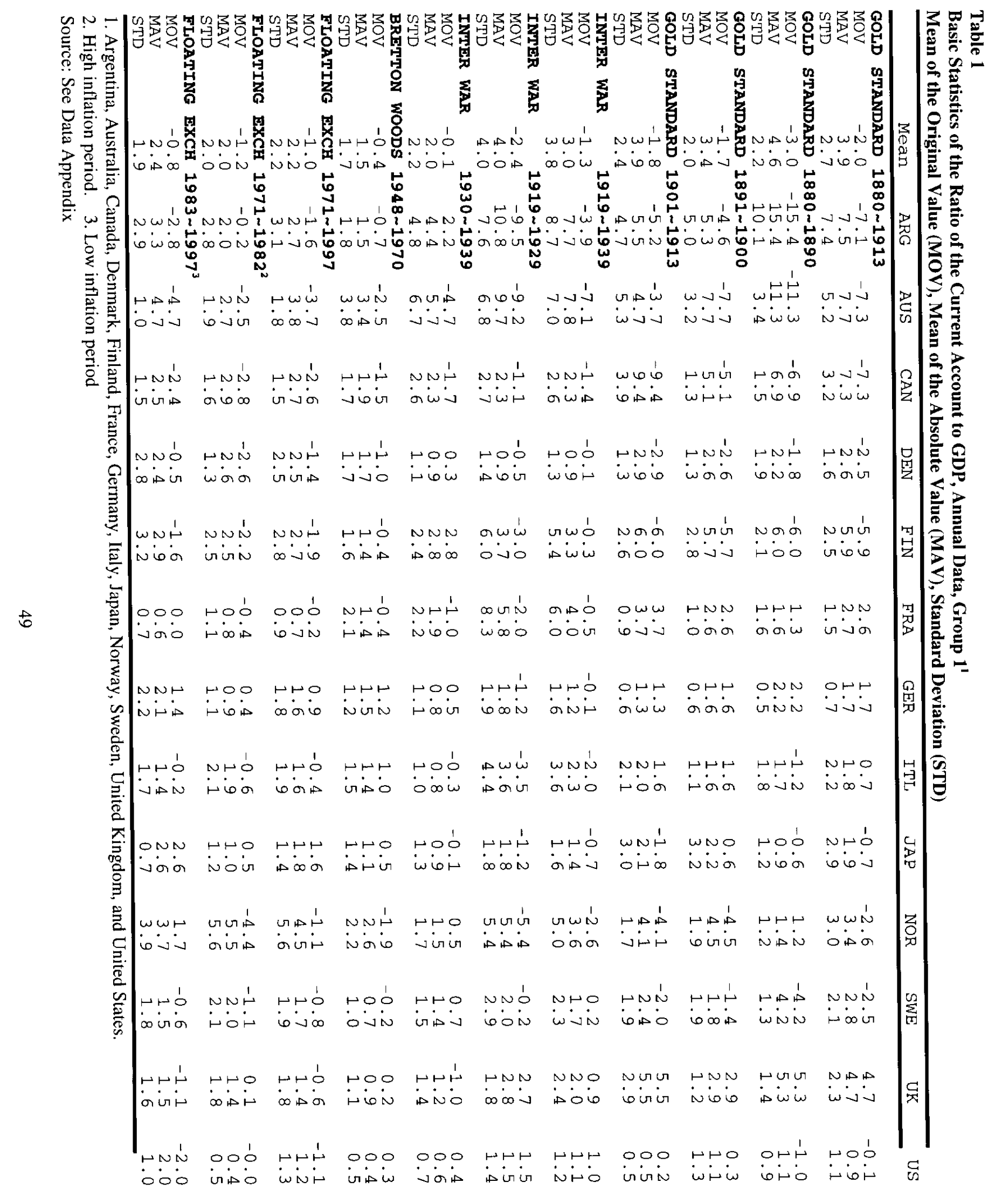




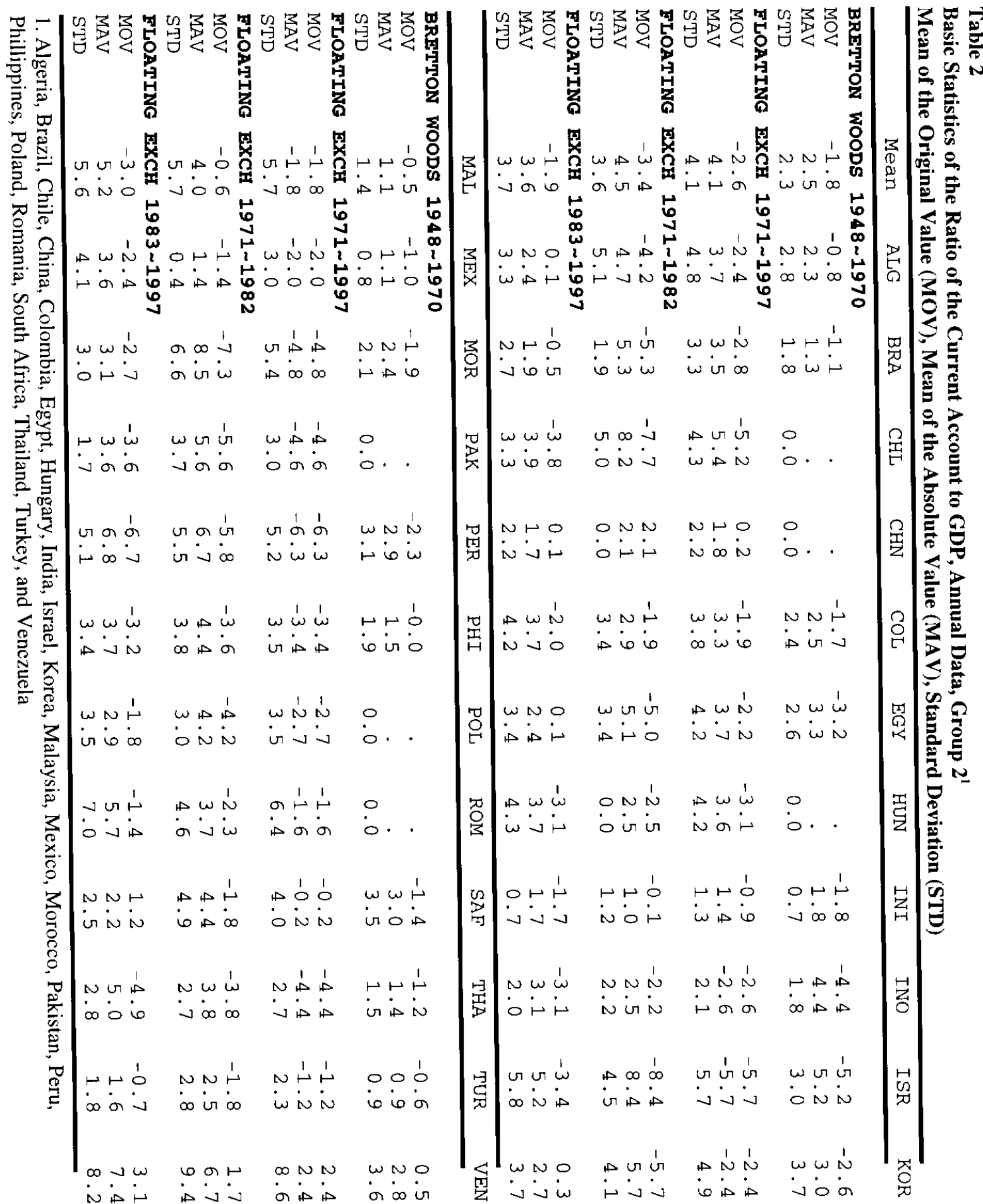




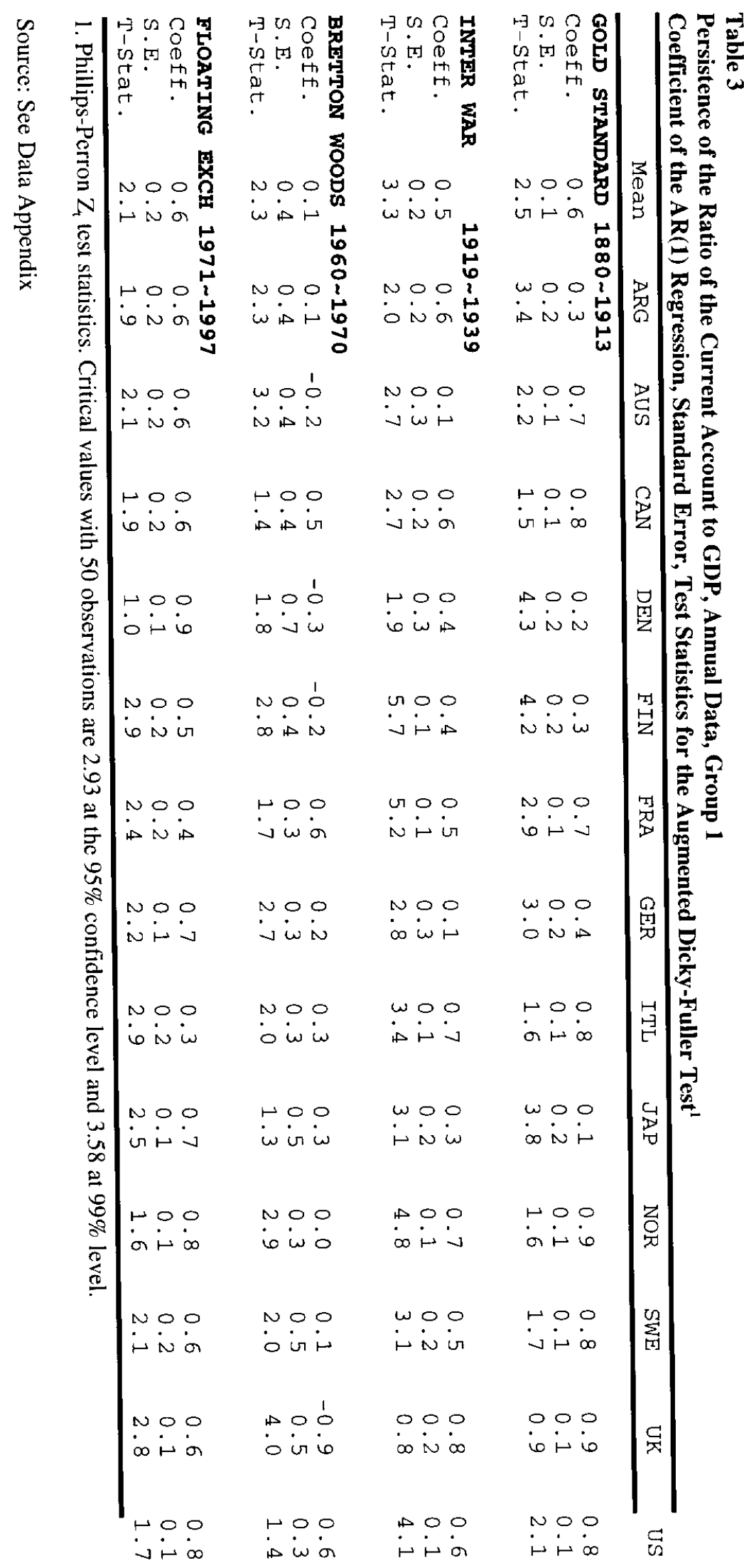




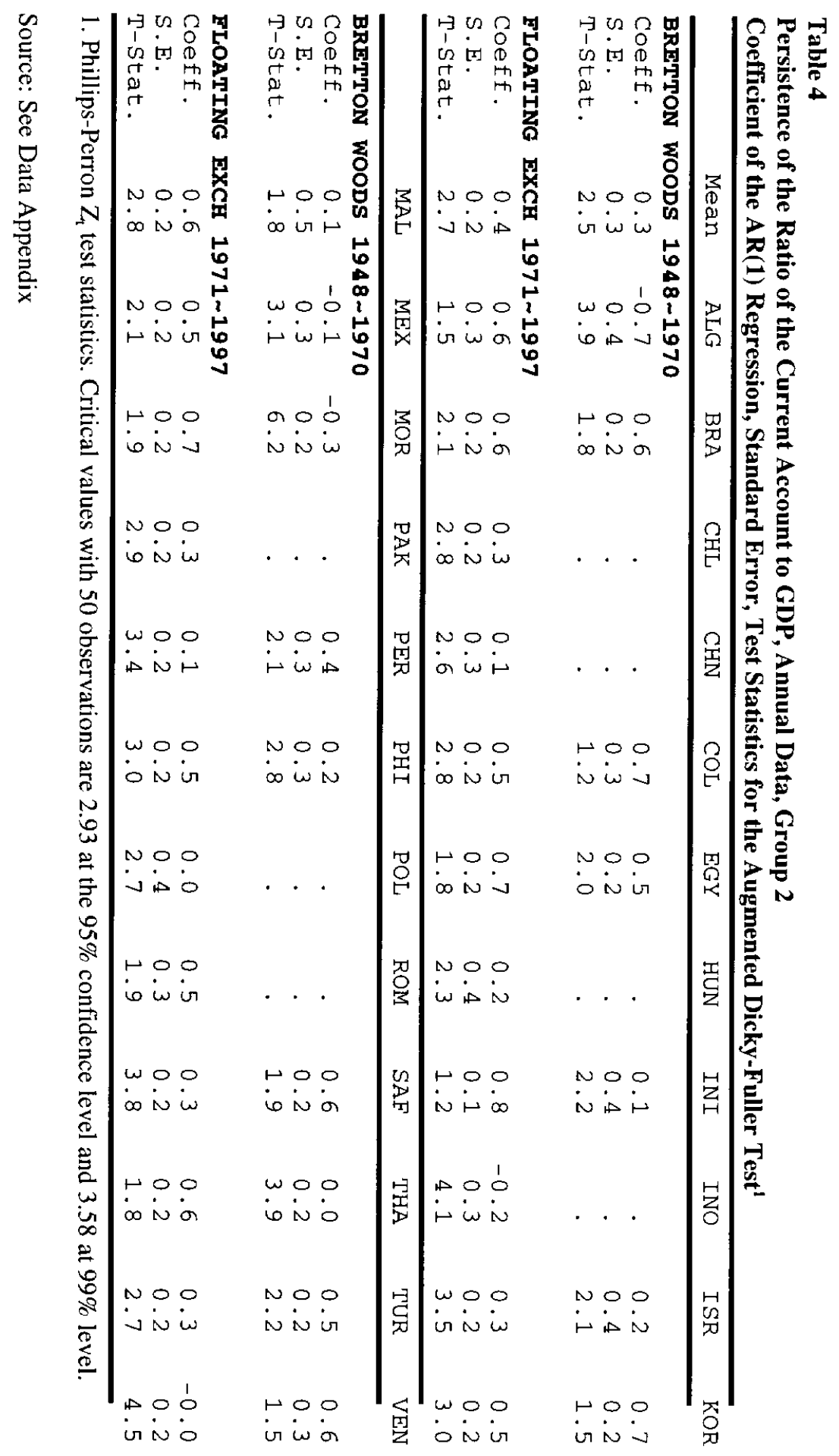


Table 5

Basic Statistics of Short-Term Nominal Interest Rates, Monthly Data, G4

Mean, Standard Deviation (STD), and Deviation among the $\mathbf{G 4}^{1}$

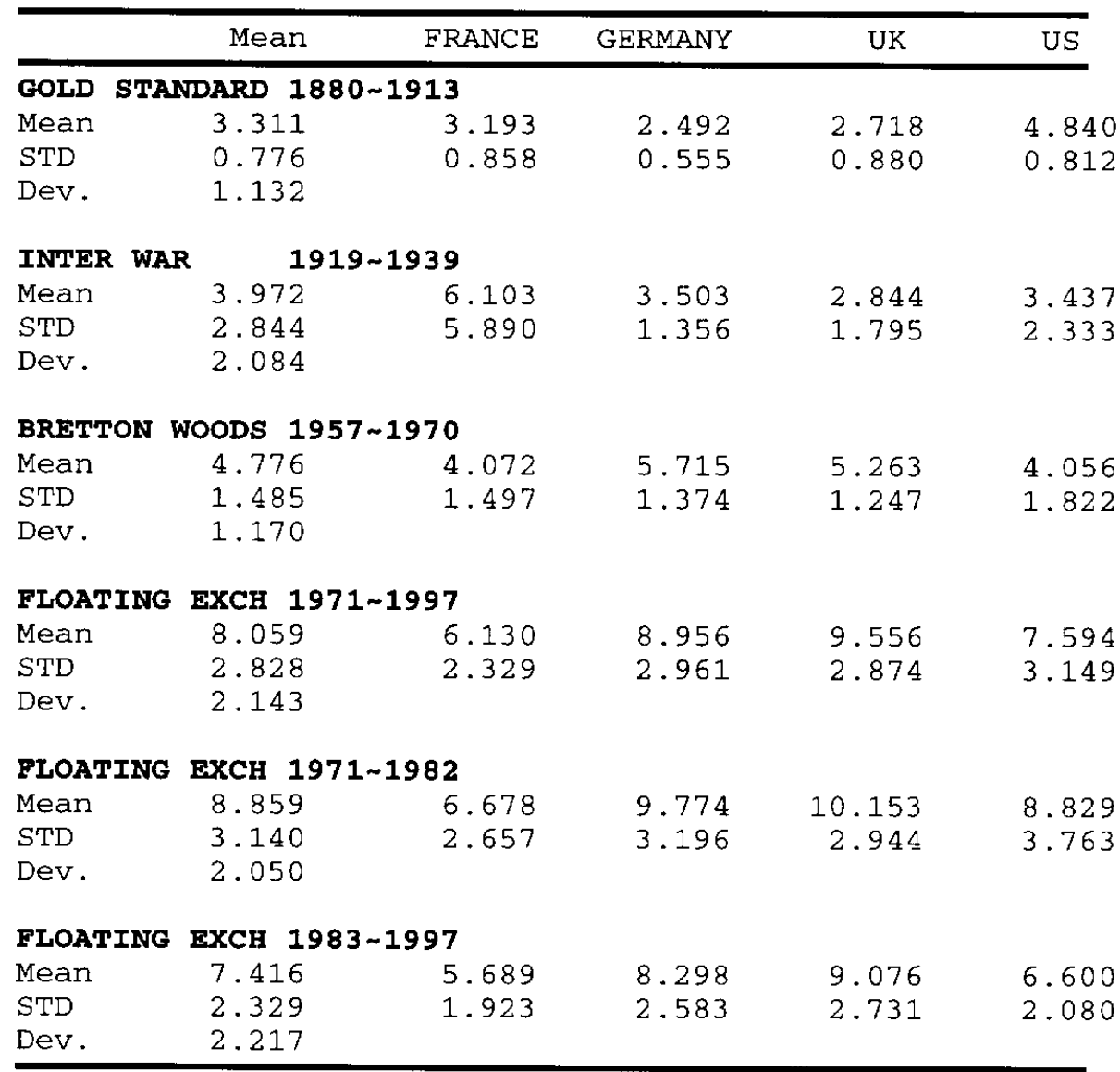

1. The deviation among the G4 was calculated as the mean of each year's standard deviation of $\mathrm{G} 4$ interest rates.

Source: See Data Appendix 
Table 6

Persistence of Short-Term Nominal Interest Rates, Monthly Data, G4

Coefficient of the AR(1) Regression, Standard Error, Test Statistic for the Augmented Dicky-Fuller Test ${ }^{1}$

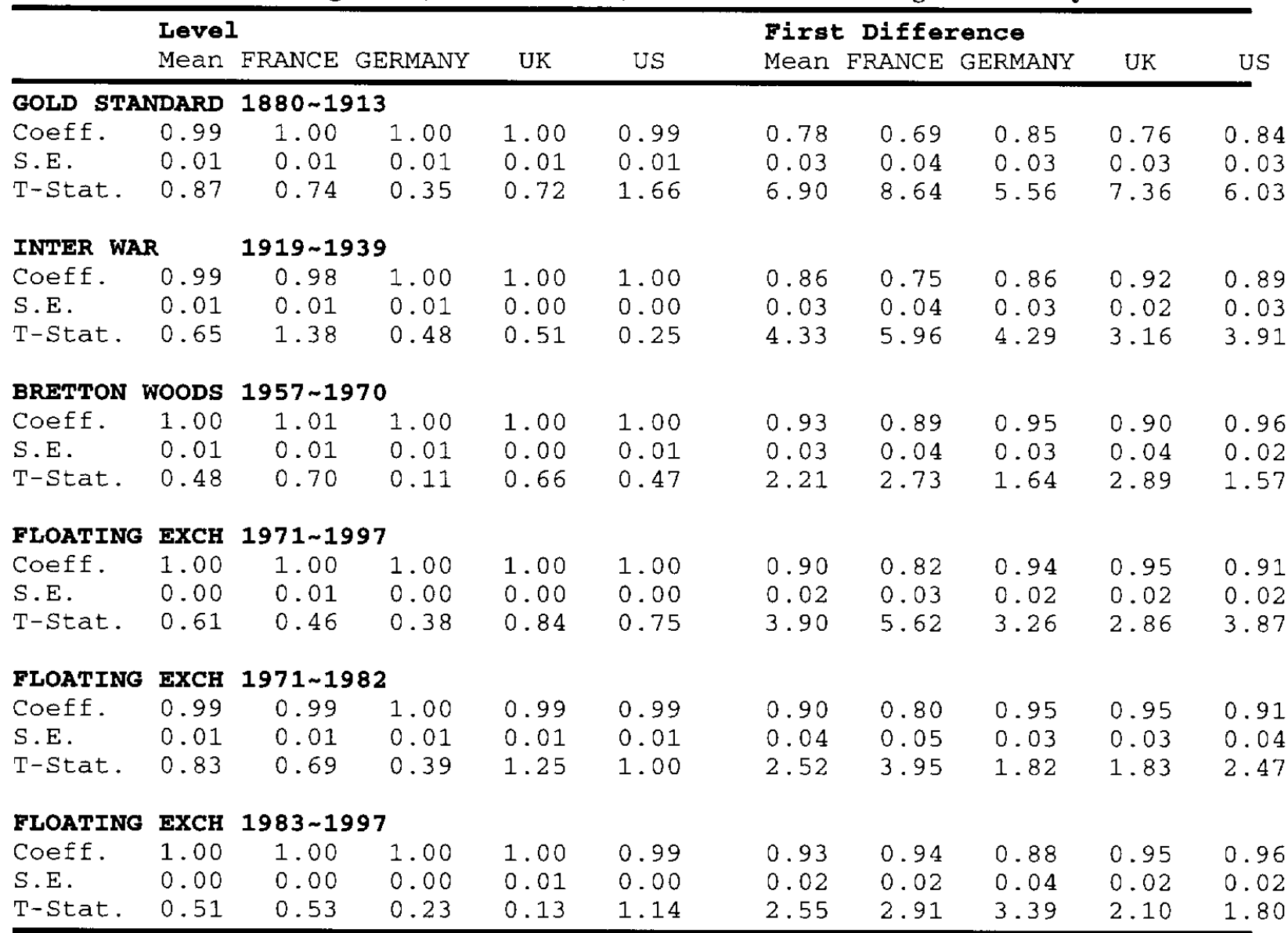

1. Phillips-Perron $Z_{4}$ test statistics. Critical values with 50 observations are 2.93 at the $95 \%$ confidence level and 3.58 at $99 \%$ level.

Source: See Data Appendix 
Table 7

Basic Statistics of Short-Term Real Interest Rates, Monthly Data, G4

Mean, Standard Deviation (STD), and Deviation among the G4 $^{1}$

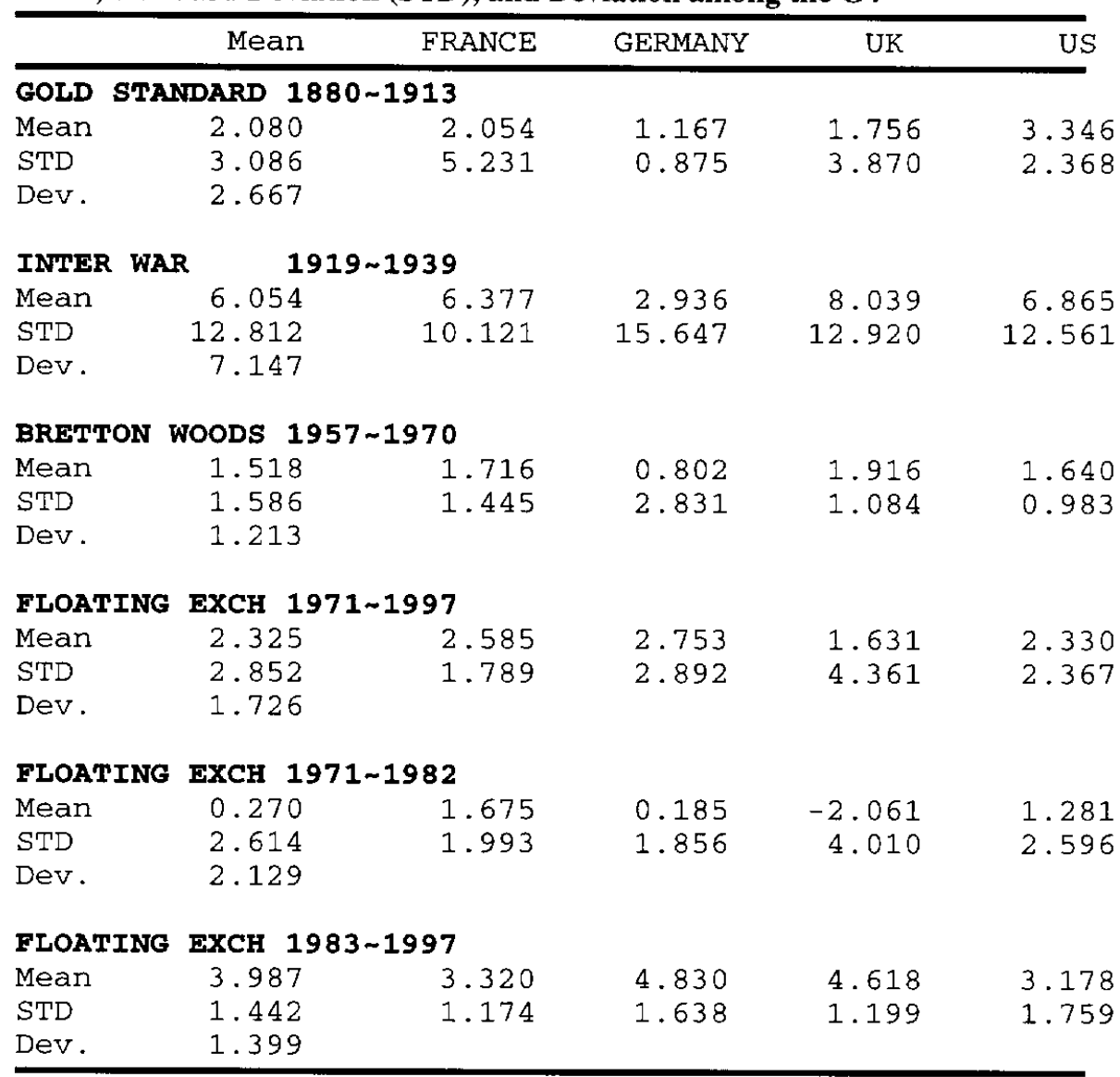

1. The deviation among the G4 was calculated as the mean of each year's standard deviation of $\mathrm{G} 4$ interest rates.

Source: See Data Appendix 
Table 8

Persistence of Short-Term Real Interest Rates, Monthly Data, G4

Coefficient of the AR(1) Regression, Standard Error, Test Statistic for the Augmented Dicky-Fuller Test ${ }^{1}$

\begin{tabular}{|c|c|c|c|c|c|c|c|c|c|c|}
\hline \multicolumn{6}{|c|}{ Level } & \multicolumn{5}{|c|}{ First Difference } \\
\hline & Mean & FRANCE & GERMANY & UK & US & Mean & FRANCE & GERMANY & UK & US \\
\hline \multicolumn{11}{|c|}{ GOLD STANDARD $1880 \sim 1913$} \\
\hline Coeff. & 0.99 & 0.99 & 0.99 & 0.99 & 0.99 & 0.91 & 0.91 & 0.87 & 0.94 & 0.91 \\
\hline S.E. & 0.01 & 0.01 & 0.00 & 0.01 & 0.01 & 0.03 & 0.03 & 0.03 & 0.02 & 0.02 \\
\hline T-stat. & 1.26 & 1.01 & 1.93 & 0.99 & 1.09 & 3.53 & 3.46 & 4.10 & 2.83 & 3.74 \\
\hline \multicolumn{2}{|c|}{ INTER WAR } & \multicolumn{2}{|c|}{$1919 \sim 1939$} & & & & & & & \\
\hline Coeff. & 0.98 & 0.95 & 0.98 & 0.98 & 0.99 & 0.92 & 0.80 & 0.95 & 0.96 & 0.97 \\
\hline S.E. & 0.01 & 0.02 & 0.01 & 0.01 & 0.01 & 0.02 & 0.04 & 0.02 & 0.02 & 0.02 \\
\hline T-Stat. & 1.87 & 2.53 & 1.75 & 1.89 & 1.32 & 2.72 & 5.04 & 2.17 & 1.88 & 1.80 \\
\hline \multicolumn{2}{|c|}{ BRETTON WOODS } & \multicolumn{2}{|c|}{$1957-1970$} & & & & & & & \\
\hline Coeff. & 0.98 & 0.99 & 0.96 & 1.01 & 0.97 & 0.90 & 0.88 & 0.92 & 0.89 & 0.92 \\
\hline S.E. & 0.01 & 0.01 & 0.01 & 0.01 & 0.01 & 0.04 & 0.04 & 0.03 & 0.04 & 0.03 \\
\hline T-Stat. & 2.29 & 0.54 & 5.38 & 0.38 & 2.86 & 2.67 & 2.74 & 2.58 & 2.80 & 2.58 \\
\hline \multirow{2}{*}{$\begin{array}{l}\text { FLOATING } \\
\text { Coeff. }\end{array}$} & EXCH & \multicolumn{2}{|c|}{ 1971 1997 } & & & & & & & \\
\hline & 1.00 & 0.99 & 1.00 & 1.00 & 0.99 & 0.87 & 0.75 & 0.91 & 0.94 & 0.87 \\
\hline S.E. & 0.00 & 0.01 & 0.00 & 0.00 & 0.01 & 0.03 & 0.04 & 0.02 & 0.02 & 0.03 \\
\hline T-Stat. & 0.86 & 0.85 & 0.66 & 0.86 & 1.06 & 4.65 & 6.79 & 3.95 & 3.24 & 4.63 \\
\hline \multirow{2}{*}{$\begin{array}{l}\text { FLOATING } \\
\text { Coeff. }\end{array}$} & EXCH & \multicolumn{2}{|c|}{$1971 \sim 1982$} & & & & & & & \\
\hline & 1.00 & 0.99 & 1.00 & 1.00 & 1.00 & 0.86 & 0.71 & 0.92 & 0.95 & 0.87 \\
\hline S.E. & 0.01 & 0.01 & 0.01 & 0.01 & 0.01 & 0.04 & 0.06 & 0.03 & 0.03 & 0.04 \\
\hline T-Stat. & 0.29 & 0.85 & 0.24 & 0.02 & 0.04 & 3.10 & 4.87 & 2.42 & 2.00 & 3.09 \\
\hline \multirow{2}{*}{$\begin{array}{l}\text { FLOATING } \\
\text { Coeff. }\end{array}$} & EXCH & \multicolumn{2}{|c|}{$1983 \sim 1997$} & & & & & & & \\
\hline & 1.00 & 1.00 & 1.00 & 1.00 & 0.99 & 0.88 & 0.90 & 0.87 & 0.84 & 0.90 \\
\hline S.E. & 0.01 & 0.01 & 0.01 & 0.01 & 0.01 & 0.03 & 0.03 & 0.04 & 0.04 & 0.03 \\
\hline T-Stat. & 0.54 & 0.05 & 0.55 & 0.51 & 1.06 & 3.46 & 3.10 & 3.43 & 4.13 & 3.18 \\
\hline
\end{tabular}

1. Phillips-Perron $Z_{1}$ test statistics. Critical values with 50 observations are 2.93 at the $95 \%$ confidence level and 3.58 at $99 \%$ level.

Source: See Data Appendix 
Table 9

Recursive Cointegration Test

Short-Term Real Interest Rates, Monthly Data, G4

Test Statistics of the Johansen Trace Likelihood Ratio Test ${ }^{1}$

\begin{tabular}{|c|c|c|c|c|c|}
\hline & $\begin{array}{l}\text { Average Test } \\
\text { Statistics }\end{array}$ & $\begin{array}{c}\text { Test } \\
908\end{array}$ & $\begin{array}{c}\text { Test } \\
95 \%\end{array}$ & $\begin{array}{l}\text { Test } \\
97.5 \%\end{array}$ & $\begin{array}{c}\text { Test } \\
99 \%\end{array}$ \\
\hline COLD STANDARD & $\begin{array}{c}1880 \sim 1913 \\
50.94\end{array}$ & rejected & rejected & & \\
\hline INTER WAR & $\begin{array}{c}1919 \sim 1939 \\
52.16\end{array}$ & rejected & rejected & rejected & \\
\hline BRETTON WOODS & $\begin{array}{c}1957 \sim 1970 \\
47.22\end{array}$ & rejected & & & \\
\hline FLOATING EXCH & $\begin{array}{c}1971 \sim 1997 \\
57.67\end{array}$ & rejected & rejected & rejected & \\
\hline FLOATING EXCH & $\begin{array}{c}1971 \sim 1982 \\
57.36\end{array}$ & rejected & rejected & rejected & rejected \\
\hline FLOATING EXCH & $\begin{array}{c}1983 \sim 1997 \\
57.97\end{array}$ & rejected & rejected & rejected & rejected \\
\hline
\end{tabular}

1. The null hypothesis is "There is no cointegration vector".

2. Average of test statistics which are calculated with fixed window size of 60 months.

The window is rolling and updated.

3. Critical values with 400 observations are 45.248 at the $90 \%$ confidence level, 48.419 at $95 \%$,

51.805 at $97.5 \%$, and 55.551 at $99 \%$ level.

Source: See Data Appendix 
Table 10

The Speed of Adjustment to Equilibrium

Short-Term Real Interest Rates, Monthly Data, G4

Coefficient $\alpha$ of VECM ${ }^{1}$

\begin{tabular}{|c|c|c|c|c|c|}
\hline & Mean & France & Germany & UK & US \\
\hline \multicolumn{6}{|c|}{ GOLD STANDARD $1880 \sim 1913$} \\
\hline & 0.013 & -0.001 & 0.060 & 0.024 & -0.031 \\
\hline \multirow[t]{2}{*}{ INTER WAR } & $1919-1939$ & & & & \\
\hline & -0.307 & -0.117 & -1.013 & -0.063 & -0.033 \\
\hline \multicolumn{6}{|c|}{ BRETTON WOODS $1957 \sim 1970$} \\
\hline & -0.031 & 0.006 & -0.034 & -0.052 & -0.043 \\
\hline \multicolumn{6}{|c|}{ FLOATING EXCH 1971 1997 } \\
\hline & -0.007 & 0.008 & -0.034 & -0.020 & 0.019 \\
\hline \multicolumn{6}{|c|}{ FLOATING EXCH 1971 1982 } \\
\hline & -0.009 & -0.012 & -0.033 & -0.012 & 0.022 \\
\hline \multicolumn{6}{|c|}{ FLOATING EXCH $1983 \sim 1997$} \\
\hline & 0.004 & 0.003 & -0.013 & 0.030 & -0.005 \\
\hline
\end{tabular}

1. The long-run error correction coefficient matrix $\Pi$ is factorized as $\alpha \beta^{\mathrm{T}}$ after $\beta$ is normalized.

Source: See Data Appendix 


\section{Appendix Figure 1. Ratio of the Current Account to GDP}
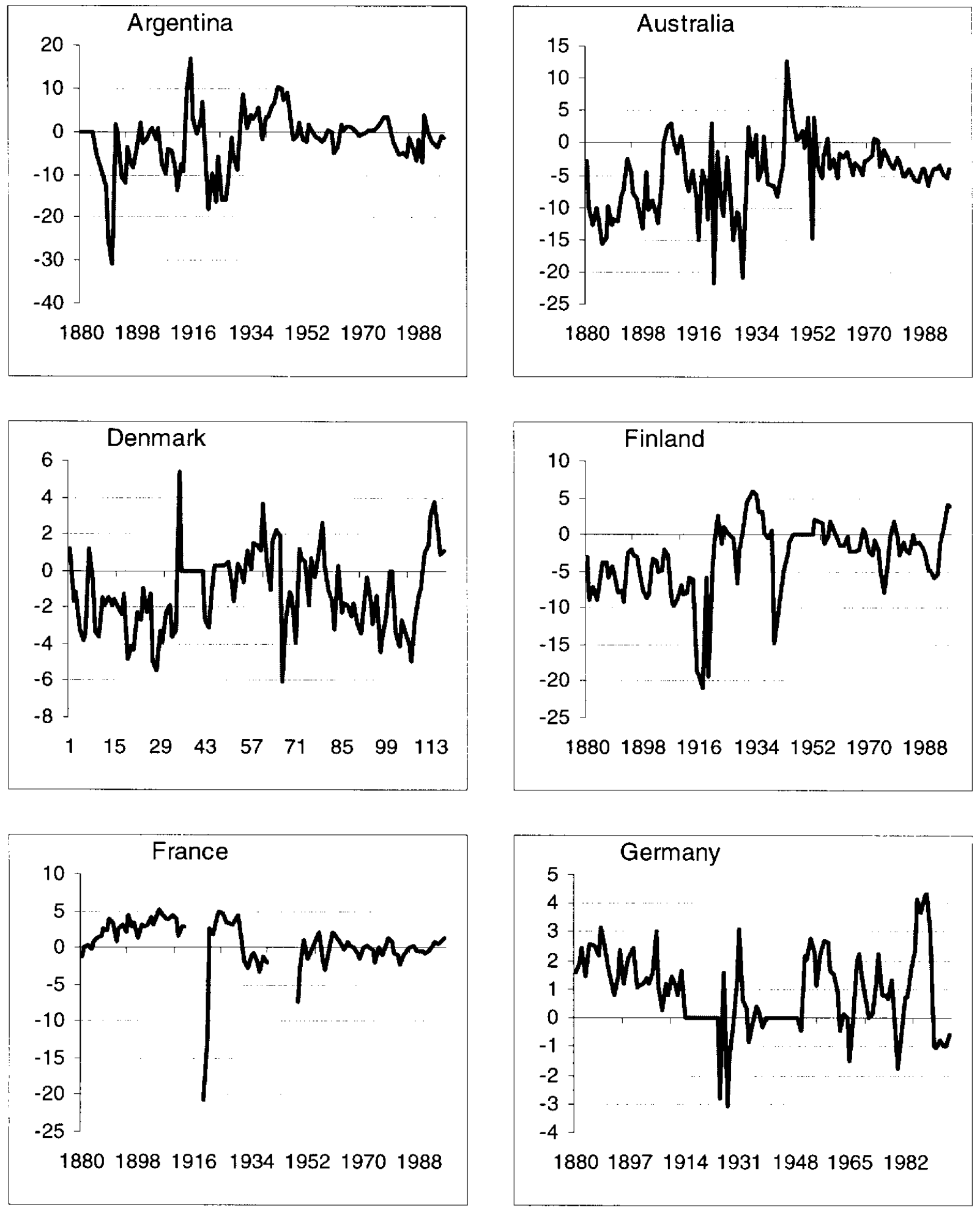

Source: See Data Appendix 

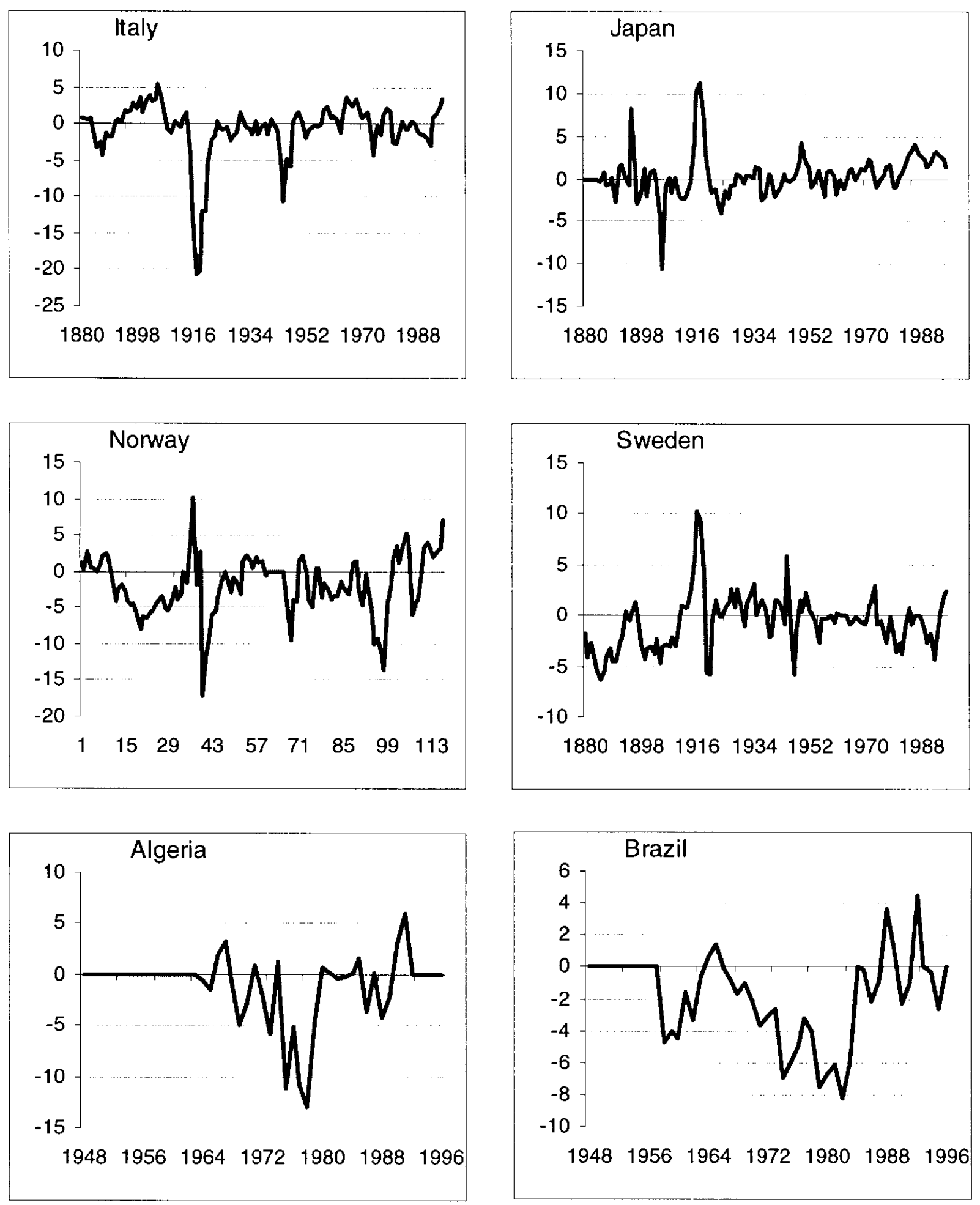

Source: See Data Appendix 

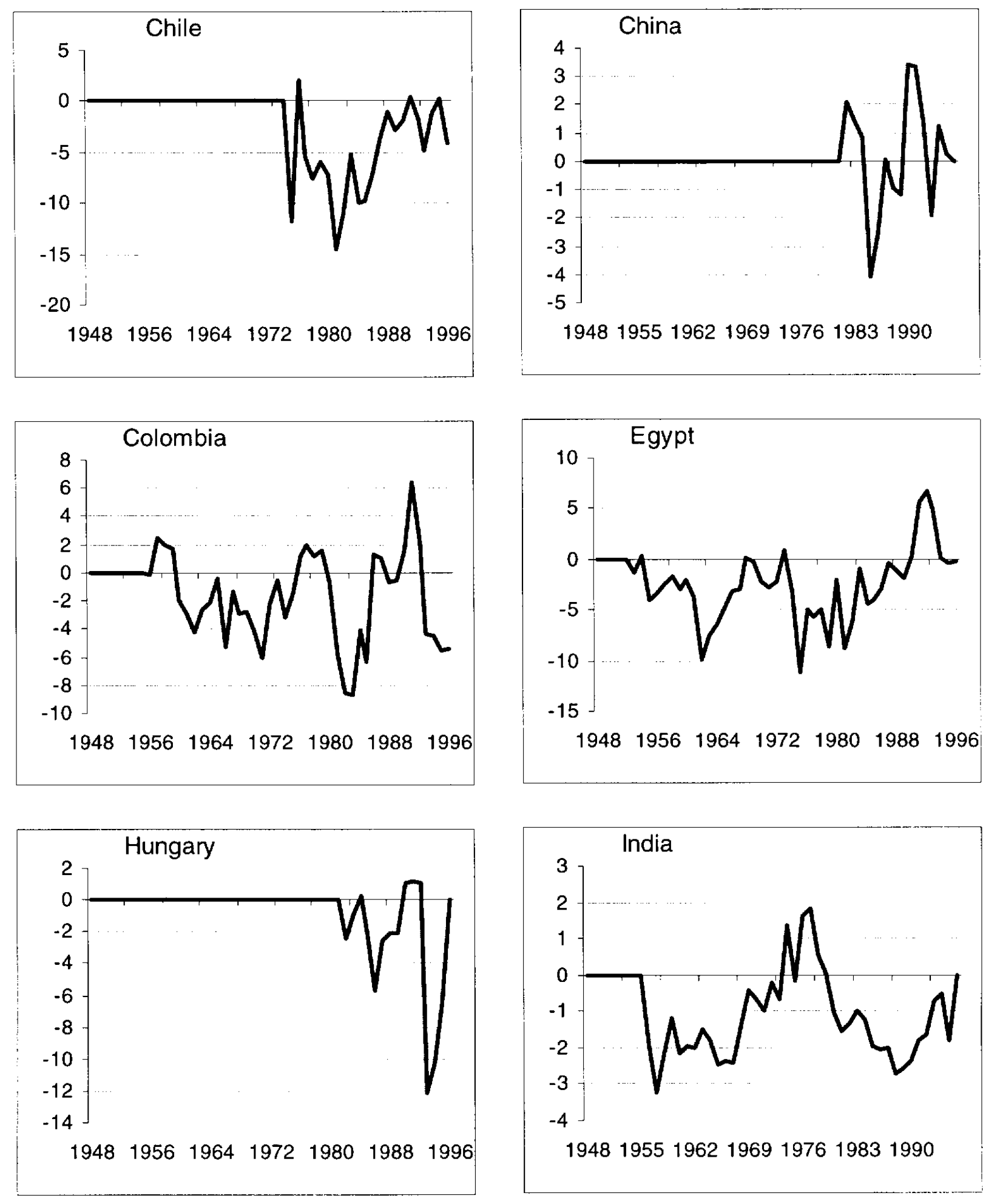

Source: See Data Appendix 

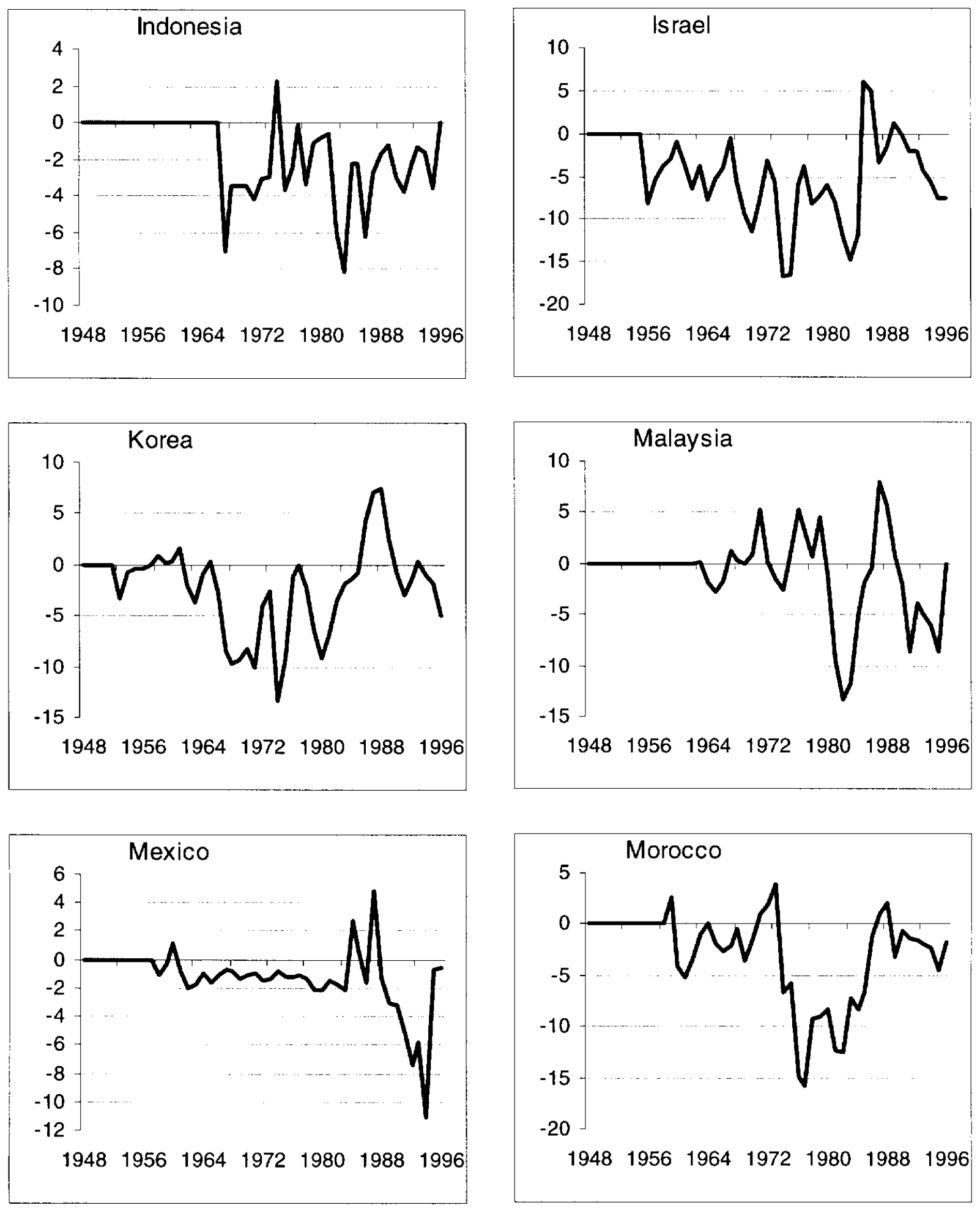

Source: See Data Appendix 

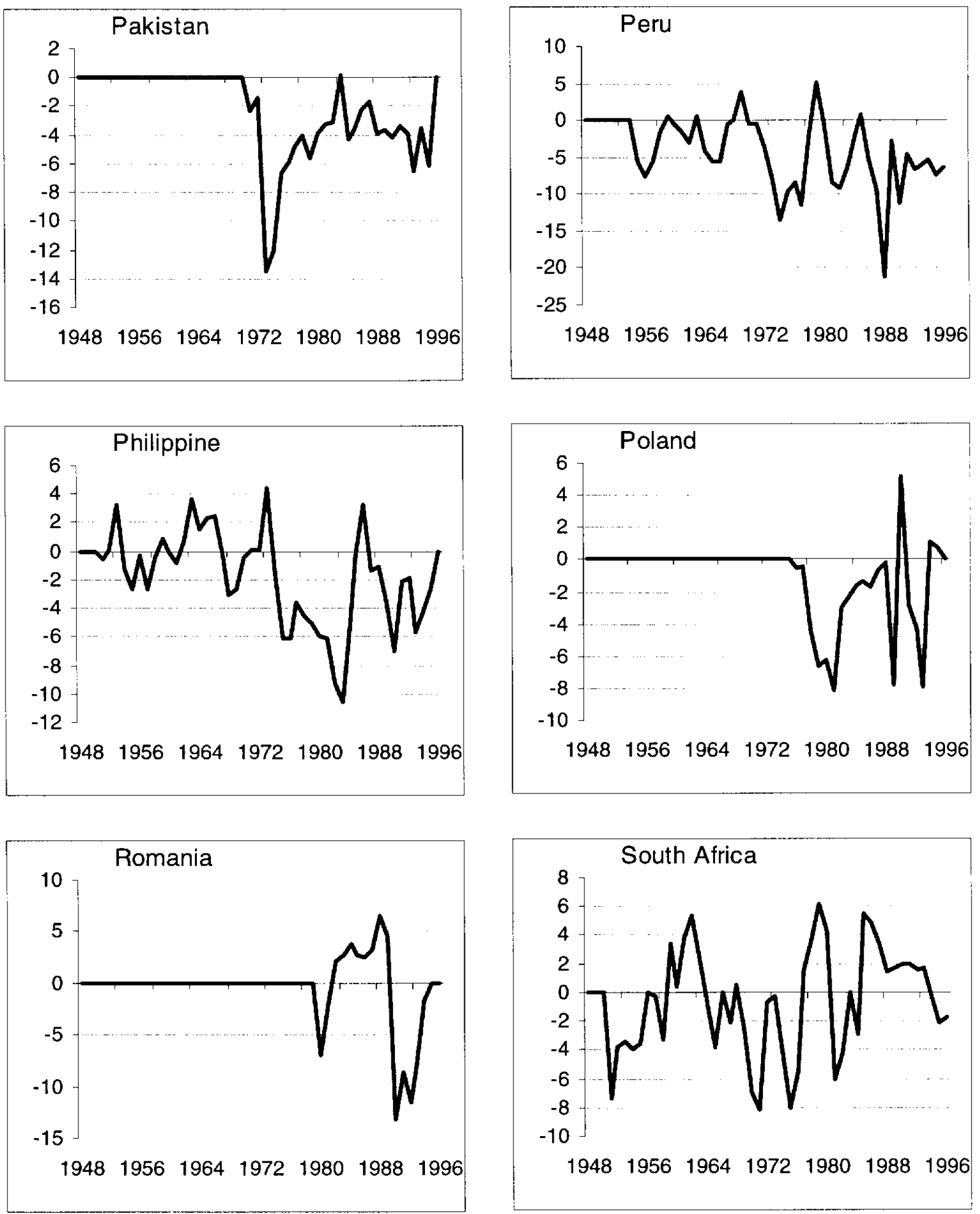

Source: See Data Appendix 

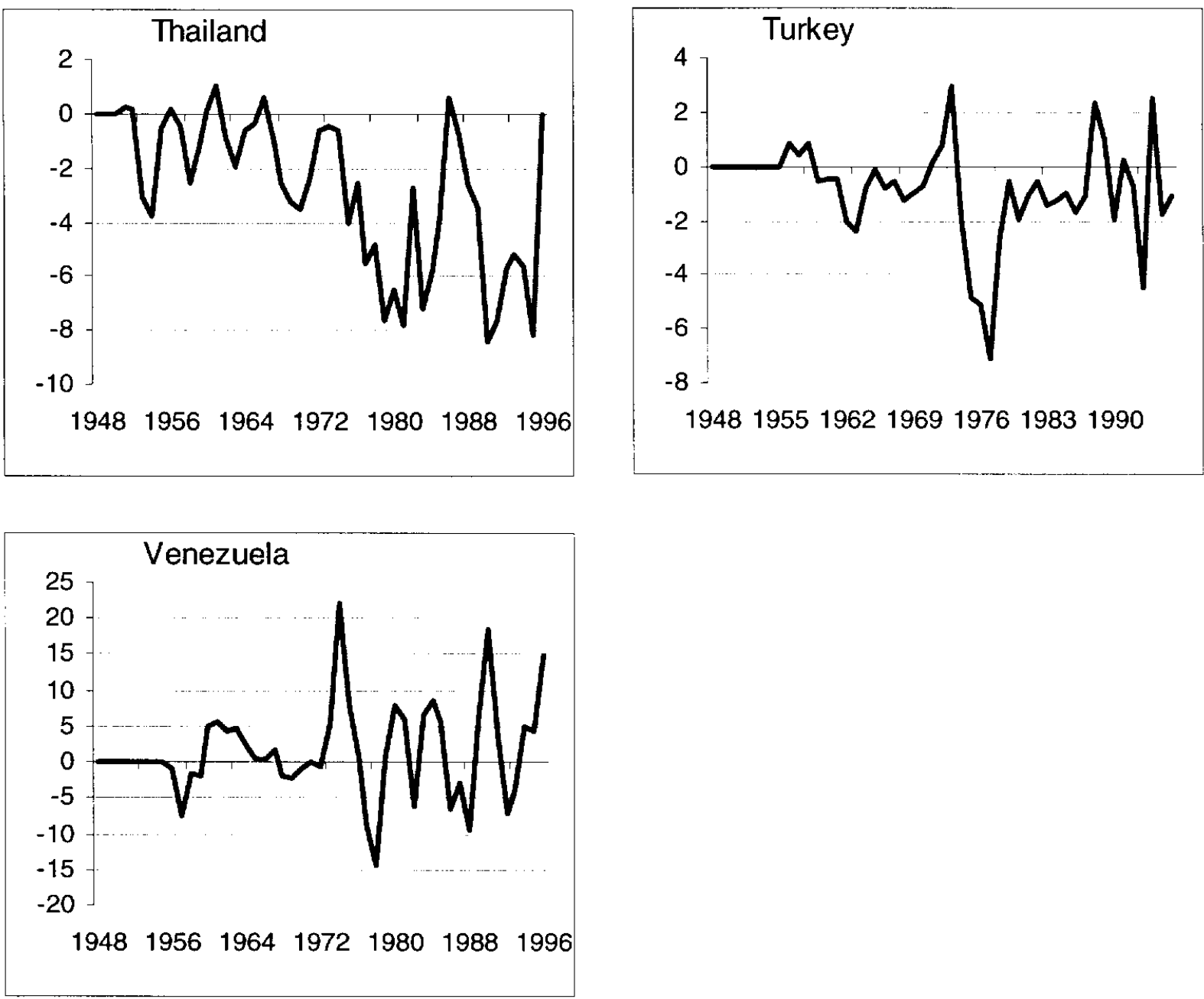

Source: See Data Appendix 


\section{Data Appendix}

Group 1: 13 countries, $\underline{1880-1996}$

Argentina, Australia, Canada, Denmark, Finland, France, Germany, Italy, Japan, Norway, Sweden, United Kingdom, and United States.

Group 2: 23 countries, 1949-1996

Algeria, Brazil, Chile, China, Colombia, Egypt, Hungary, India, Israel, Korea, Malaysia, Mexico, Morocco, Pakistan, Peru, Phillippines, Poland, Romania, South Africa, Thailand, Turkey, and Venezuela

(1) Current Account, Annual Data $\underline{1880-1945}$

Australia, Canada, Denmark, Finland, France, Germany, Italy, Japan, Norway, Sweden, United Kingdom, and United States in Jones, Matthew T. and Maurice Obstfeld (1997), "Saving, Investment, and Gold: A Reassessment of Historical Current Account Data", NBER Working Paper Series 6103. Non-gold current account which excludes all gold flows. Argentina in Taylor Alan M. (1996), "International Capital Mobility in History: The SavingInvestment Relationship", NBER Working Paper Series 5743.

1949-1974

Group 1 and Group 2 (except China, Hungary, Poland, and Romania) in International Monetary Fund (1979), International Financial Statistics Yearbook.

1975-1996

Group 1 and Group 2 in International Monetary Fund (1998), International Financial Statistics (IFS), CD-ROM.

(2) Nominal National Income, Various Definitions, Annual Data 1880-1945

Australia, Canada, Denmark, Finland, France, Germany, Italy, Japan, Norway, Sweden, United Kingdom, and United States in Jones, Matthew T. and Maurice Obstfeld (1997).

Argentina in Bordo, Michael D. and Anna J. Schwartz (1996) "The Operation of the Specie Standard: Evidence for Core and Peripheral Countries, 1880-1990" In Currency Convertibility: The Gold Standard and Beyond eds. Jorge Braga de Macedo, Barry Eichengreen and Jaime Reis. 1949-1996

Group 1 and Group 2 in International Monetary Fund (1998), International Financial Statistics (IFS), CD-ROM. Nominal GDP

(3) Population, Annual Data $\underline{1880-1945}$

Bordo and Schwartz (1996).

1949-1996

IFS CD-ROM (1998). 
(4) Foreign Exchange Rates, Annual Data

$\underline{1880-1939}$

Domestic Currency / US Dollar in Bordo and Schwartz (1996).

$\underline{1949-1996}$

Domestic Currency / US Dollar in IFS CD-ROM (1998).

(5) Exchange Rate Regime, Annual Data

Sources:

$\underline{1880-1939}$ and $1946-1960$

Bordo, Michael D. and Anna J. Schwartz (1996), Table 2.1 and Table 2.2

1961-1989

Ghosh, Atish R., Anne-Marie Gulde, Jonathan D. Ostry, and Holger C. Wolf (1995), "Does the Nominal Exchange Rate Regime Matter ?" IMF Working Paper, Appendix I and II, Exchange Rate Regime Classification.

$\underline{1990-1996}$

International Monetary Fund (1997), International Financial Statistics Yearbook, p 18, Exchange Rate Arrangement.

For $1880-1939$, exchange rate regime dummy $=0$ if a country has a gold convertible regime, 1 otherwise. After 1946, exchange rate regime dummy $=0$ if a country has a fixed exchange rate regime, 1 if a country has a floating exchange rate regime.

Note: Cooperative arrangements (European Monetary System) are classified as a fixed exchange rate regime.

(6) Capital Controls, Annual Data

Sources:

$\underline{1951-1996}$

Data are from elaborations on IMF Annual Report on Exchange Rate Arrangements and Exchange Restrictions, various issues.

Capital controls (current account) dummy $=1$ if a country has restrictions on its current account, 0 otherwise. Capital controls (capital account) dummy $=1$ if a country has restrictions on its capital account, 0 otherwise.

(7) Short-Term Interest Rates, Various Definitions, Monthly Data 1880-1914

France, Germany, United Kingdom, and United States in Bordo, Michael D. and Ronald MacDonald (1997), "Violations of the 'Rules of the Game' and the Credibility of the Classical Gold Standard, 1880-1914", Global Economic Institutions (GEI) Working Paper Series 28. $\underline{1919-1939}$

France, Germany, United Kingdom, and United States in Bordo, Michael D. and Ronald MacDonald (1998), "The Interwar Gold Exchange Standard: A Credible System?" mimeo. 1957-1997

France, Germany, United Kingdom, and United States in IFS CD-ROM (1998).

France: 1957:01-1963:12 government bond yield, 1964:01-1997:12 call money rate.

Germany: 1957:01-1959:12 government bond yield, 1960:01-1997:12 call money rate. 
United Kingdom: 1957:01-1963:12 government bond yield, 1964:01-1997:12 treasury bill rate. United States: 1957:01-1963:12 federal fund rate, 1964:01-1997:12 treasury bill rate.

(8) Prices, Various Definitions, Monthly Data

1880-1914

France, Germany, United Kingdom, and United States in Bordo, Michael D. and Ronald MacDonald (1997). Wholesale Price Index (WPI).

1919-1939

France, Germany, United Kingdom, and United States in Bordo and MacDonald (1998).

Wholesale Price Index (WPI).

$\underline{1957-1997}$

France, Germany, United Kingdom, and United States in IFS CD-ROM (1998). Consumer Price Index (CPI). 